August 2002 - NREL/TP-820-32169

\title{
Assessment of the DOE/NREL Historically Black College and University Photovoltaic Research Associates Program
}

F. Posey Eddy and R. McConnell
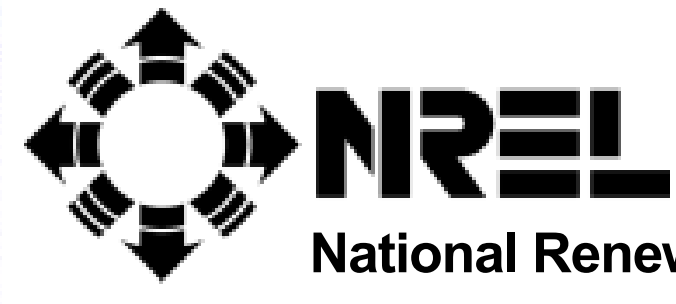

National Renewable Energy Laboratory

1617 Cole Boulevard

Golden, Colorado 80401-3393

NREL is a U.S. Department of Energy Laboratory

Operated by Midwest Research Institute $\bullet$ Battelle $\bullet$ Bechtel

Contract No. DE-AC36-99-G010337 


\title{
Assessment of the DOE/NREL Historically Black College and University Photovoltaic Research Associates Program
}

\author{
F. Posey Eddy and R. McConnell
}

Prepared under Task No. PVP2.2601

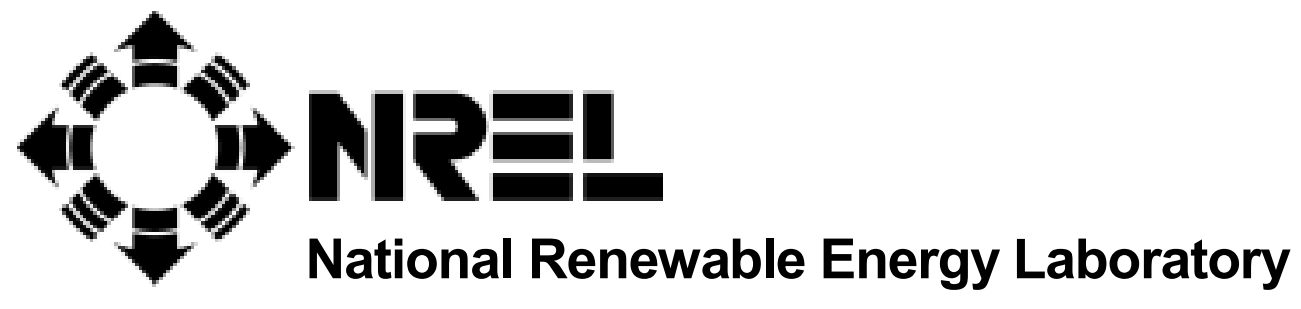

1617 Cole Boulevard

Golden, Colorado 80401-3393

NREL is a U.S. Department of Energy Laboratory

Operated by Midwest Research Institute • Battelle • Bechtel

Contract No. DE-AC36-99-G010337 


\section{NOTICE}

This report was prepared as an account of work sponsored by an agency of the United States government. Neither the United States government nor any agency thereof, nor any of their employees, makes any warranty, express or implied, or assumes any legal liability or responsibility for the accuracy, completeness, or usefulness of any information, apparatus, product, or process disclosed, or represents that its use would not infringe privately owned rights. Reference herein to any specific commercial product, process, or service by trade name, trademark, manufacturer, or otherwise does not necessarily constitute or imply its endorsement, recommendation, or favoring by the United States government or any agency thereof. The views and opinions of authors expressed herein do not necessarily state or reflect those of the United States government or any agency thereof.

Available electronically at http://www.osti.gov/bridge

Available for a processing fee to U.S. Department of Energy

and its contractors, in paper, from:

U.S. Department of Energy

Office of Scientific and Technical Information

P.O. Box 62

Oak Ridge, TN 37831-0062

phone: 865.576.8401

fax: 865.576.5728

email: reports@adonis.osti.gov

Available for sale to the public, in paper, from:

U.S. Department of Commerce

National Technical Information Service

5285 Port Royal Road

Springfield, VA 22161

phone: 800.553.6847

fax: 703.605.6900

email: orders@ntis.fedworld.gov

online ordering: http://www.ntis.gov/ordering.htm 


\section{Contents}

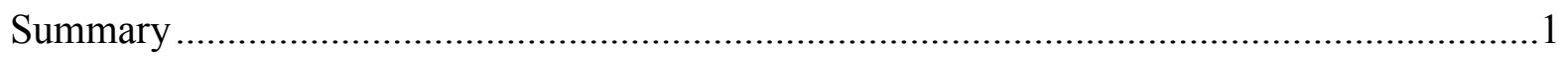

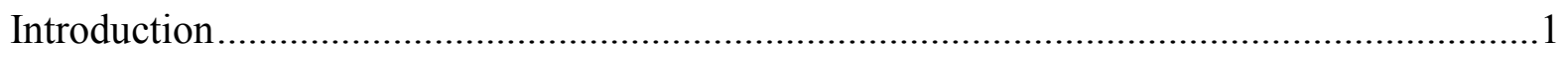

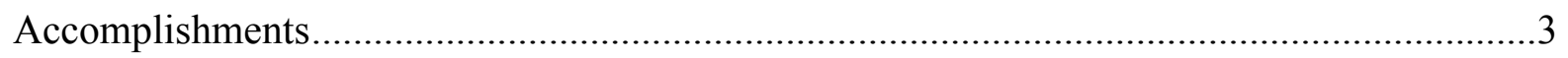

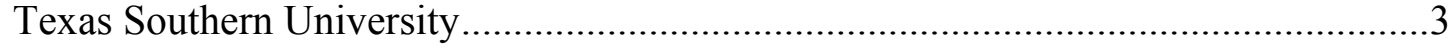

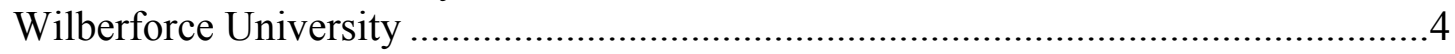

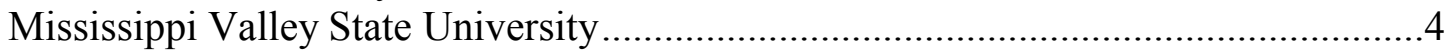

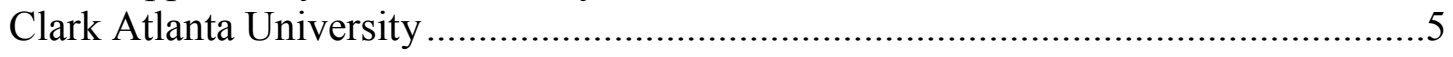

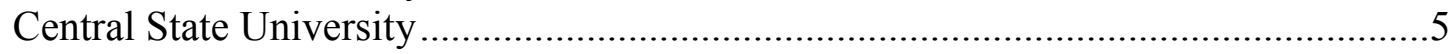

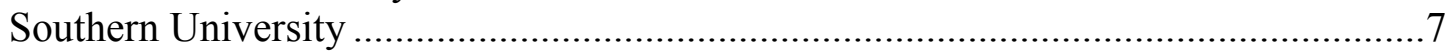

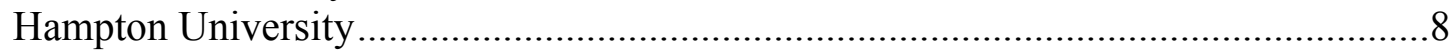

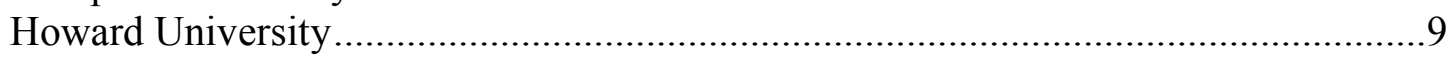

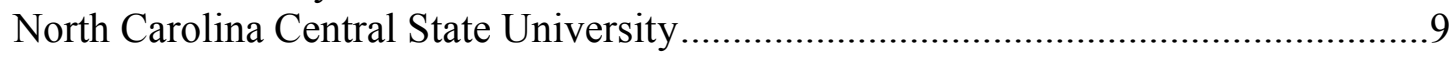

Program Highlights .............................................................................................. 10

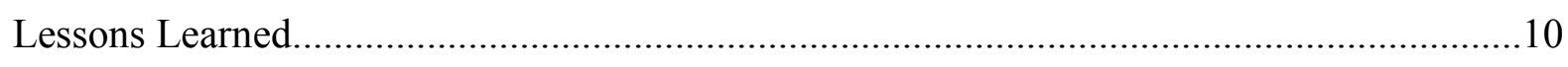

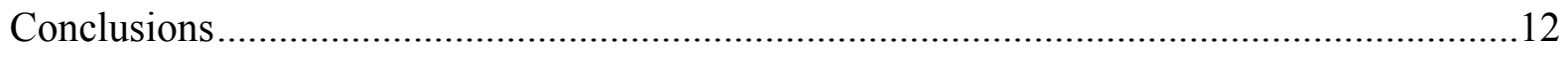

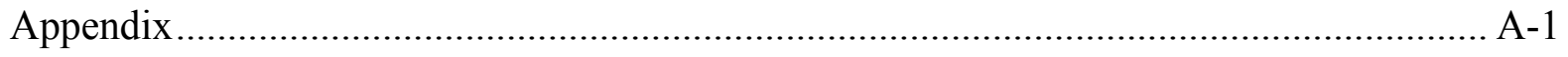




\title{
Assessment of the DOE/NREL Historically Black College and University Photovoltaic Research Associates Program
}

\author{
Fannie Posey Eddy and Robert D. McConnell \\ Office of Education Programs and Center for Basic Sciences \\ National Renewable Energy Laboratory (NREL), Golden, Colorado 80401
}

\section{Summary}

This small but remarkable program directly affected dozens of minority undergraduate students in ways that changed many of their lives. Indirectly, the program impacted thousands of young high school and undergraduate students as a result of many renewable energy outreach projects. The progress and accomplishments of the undergraduates were monitored and assessed through their presentations at an annual NREL-sponsored Historically Black College and University (HBCU) conference. Although the funding was small, typically $\$ 400,000$ per year, the money made a significant impact. The best students sometimes went on to the nation's top graduate schools (e.g., MIT) or important management positions in large companies. Other students had opportunities to learn how renewable energy could positively affect their lives and their neighbors' lives. A few were lucky enough to install photovoltaic (PV) lighting and waterpumping systems in Africa, and to see and feel firsthand the technical and emotional benefits of this technology for families and villages. Two of the schools, Texas Southern University and Central State University, were particularly successful in leveraging their DOE/NREL funding to obtain additional funding for expanded programs.

This assessment describes the activities funded at nine HBCUs beginning in 1995 . The PV projects involved laboratory research, solar resource measurements, system studies, architecture, and field projects in Africa. Some projects involved other renewable energy technologies or other energy-related technologies as dictated by expertise of the HBCU principal investigator.

Because of this program's successes, we recommend a continuation and expansion of this program to include all minority-serving colleges and universities and all solar energy technologies in the DOE Office of Solar Energy Technologies. This expansion would allow Hispanic and Native American schools and students to be included along with the Historically Black Colleges and Universities. Expanding the program to other solar energy technologies will provide more solar energy project opportunities, beyond just photovoltaic projects. Even more specifically, one part of this program could help provide needed and valuable solar resource data over much of the United States through a network of minority institutions collecting such data.

\section{Introduction}

The National Photovoltaics Program Plan for the U.S. Department of Energy (DOE), published in January 2000, calls for an assessment in 2002 of its program for funding undergraduate students at the nation's Historically Black Colleges and Universities (HBCUs). Since 1995, DOE and the National Renewable Energy Laboratory (NREL) have funded nine HBCUs in its 
HBCU Photovoltaic Research Associates Program. The program's purpose was to provide funding directly to outstanding undergraduate students (the PV research associates) for their studies and to encourage their knowledge of photovoltaics through research and outreach projects. Typically, each school's project supported one to three students per year under the guidance of a professor, although many other students often became involved either directly (when a research associate was replaced) or indirectly (as a result of research associate renewable energy activities). Two sets of 3-year contracts were awarded as a result of requests for proposals from the HBCUs. The total annual funding for all the universities was approximately $\$ 300,000$, with an additional $\$ 100,000$ annually for a summer internship program and summer outreach activities. Annual funding to each school ranged from $\$ 20,000$ (supporting one associate) to $\$ 60,000$ per year (supporting three).

The contracted HBCUs and performance periods were:

Central State University (1995-2002)

Clark Atlanta University (1995-2002)

Hampton University (1995-2002)

Howard University (1998-2002)

Mississippi Valley State University (1995-2002)

North Carolina Central State University (1998-2002)

Southern University and A\&M (1995-2002)

Texas Southern University (1995-2002)

Wilberforce University (1995-1998)

The PV projects involved laboratory research, solar resource measurements, system studies, architecture, and field projects in Africa. Some schools included community education outreach projects during the school year or during the summer. The students were encouraged each summer to continue developing their skills by working in a renewable energy-related field as a summer intern at NREL, another university, another research laboratory, or a renewable energy company. Beginning in August 1999, the HBCU advisors, students, and NREL professionals participated in an annual Renewable Energy Academic Partnership (REAP) review meeting and conference to discuss and share their research progress, future opportunities, and the national and global role of renewable energy in ensuring a secure and sustainable environment. (Research presentations from the August 2001 REAP are in Appendix A.)

The results of the last 6 years include many research accomplishments and student success stories. Seeds of scientific knowledge, accomplishment, environmental awareness, and community responsibility were planted as a result of opportunities provided by the program. Several of our students have gone on to graduate school in fields such as physics, chemistry, architecture, and engineering. Others are now working in industry and government labs, using the knowledge and expertise they gained as DOE-NREL PV associates. The impacts of this program in local and international communities occurred through student-managed community education projects, HBCU-PV workshops and installations in South Africa, and projects in Senegal and even on the NREL campus. Each HBCU team had different research projects and accomplishments. But the most valuable accomplishment has been the inspiration and motivation 
of the students to excel in their scientific quest for knowledge and to share their excitement of renewable energy with their local and international communities.

\section{Accomplishments}

\section{Texas Southern University}

For almost 7 years, the National Renewable Energy Laboratory and Texas Southern University (TSU) worked in partnership to educate TSU students. Together, the TSU College of Science and Technology and NREL have been preparing college students to meet the needs of the PV industry by providing them with opportunities to conduct PV energy research and education. The aim was to attract qualified technology, science, engineering, and business students, and allow them to consider pursuing a career in specified areas of photovoltaic technology.

The first TSU subcontract supported one student, whereas the second funded three. The development of the NREL program at TSU grew to include summer intern opportunities for associates from other HBCUs in the program. The TSU internships offered students the opportunity to gain hands-on experience in renewable energy technology in the classroom, laboratory, and in the field. These college interns also served as counselors for high school students participating in a Renewable Energy and Environmental Protection (the original REEP) Academy during the summer months. As many as 65 Texas high school students learned about renewable energy during a 4- to 6-week period that included field trips to wind sites in Texas, as well as visits to Sandia National Laboratories and NREL.

The NREL PV Research Associate Program at TSU was the foundation of its renewable energy activities. The TSU principal investigator, Dr. Joshua Hill, was able to obtain funding from the Electric Power Research Institute and Houston Lighting and Power for a 4-kW PV system complete with batteries, dc appliances, inverters, and ac appliances. NREL funding allowed TSU students to attend conferences and workshops to learn more about renewable energy technology. Over the years, students learned firsthand about renewable energy technology in both the United States and South Africa.

Dr. Hill directed the remarkably successful program at TSU until his untimely death in 2001 upon returning from a renewable energy-related trip to Nigeria. TSU's current renewable energy program director is Oral LaFleur, who was the first TSU PV research associate.

Another of the TSU/NREL students found full-time employment in renewable energy at the University of Texas (UT) Photovoltaic Center. Another former DOE/NREL student at TSU is working on a master's degree and works part time with the renewable energy program. Since the establishment of the NREL PV Research Associate Program, TSU has received several requests from industry for renewable energy-trained personnel.

Student activities in TSU's renewable energy program include community projects in which they attend public functions and demonstrate projects in renewable energy technology. Just recently, TSU students completed the installation of a $3-\mathrm{kW}$ system on a home in Houston. Another PV research associate conducted solar car demonstration projects for middle and high school 
students. These were fun, exciting, and successful learning activities for all. Other student experiences include the installation of PV systems in rural South African communities. Most recently, students from TSU and four other HBCUs installed a PV system at a preschool in South Africa. This project served as a development exercise in education and leadership for the students. Because of the installation, the preschool became the only building with electricity in the village of more than 4,000 people and is now the after-dark meeting place for the village.

The HBCU PV Research Associates Program has contributed greatly to the education and development of students at TSU. It has been recognized as one of the most successful student programs at the university. TSU hopes to continue the program to enhance and fulfill its mission to provide opportunities for minorities in science, math, and engineering.

\section{Wilberforce University}

As one of the first HBCUs in this program, Wilberforce students were introduced to photovoltaics through a hands-on approach. Several professors worked with three PV research associates on solar cell analysis, device modeling, and solar cell substrate research. Students also worked as summer interns at Texas Southern University, the Florida Solar Energy Center, and at the NASA-Glenn Research Center. Located in Wilberforce, Ohio, the university partnered on some of its student projects with its neighbors, Central State University, also in Wilberforce, and NASA-Glenn Research Center in Cleveland. When this project was successfully completed in 1998, the principal investigator and champion left Wilberforce. No one else at the school followed through with a proposal for another 3-year effort.

\section{Mississippi Valley State University}

The objective of the program at Mississippi Valley State University (MVSU) was to familiarize students with various aspects of energy-related research with a later focus on solar resource measurements. The effort supported two associates. They began by exploring what stimulated the nation's interest in solar energy. This led to the realization that regions that were optimal for solar power generation were not always near power lines or areas that used the power. The students studied factors that affected the solar power intensity profile on different surfaces. To understand power storage better, some students actually constructed battery components by electrodepositing zinc and other metals using a solar panel as the energy source. They also designed a solar tracking platform for optimization of the platform's tracking angle in expectation that they could improve the energy collected by $25 \%-50 \%$. They constructed a prototype aluminum carbon dry cell based on the Lelanche design, a zinc-air cell, and a hydrogen-oxygen fuel cell, which ran on hydrogen generated from active metals and is also electrodeposited using a solar energy source. These projects often included students other than the PV research associates, and, at one point, MVSU held a daylong seminar for all MVSU students to learn about solar energy.

The staff in the MVSU contracts' office had a great deal of difficulty in responding to all of the paperwork requirements necessary to sign a second contract when the first program finished in 1998. The first MVSU principal investigator retired and a young MVSU professor attempted to keep the effort alive with a project to serve as a hub for solar resource measurements at MVSU 
and five other HBCUs in the Southeast. Despite the interest of NREL solar resource personnel and the efforts of the young MVSU professor, a second contract was not signed because of the difficulties in completing the necessary paperwork.

\section{Clark Atlanta University}

At Clark Atlanta University (CAU), the goal of research was to determine the effects of atmospheric variability on the production of energy from solar cells. Another goal was to provide students with opportunities for obtaining a background in modeling and design optimization of solar cells. Through the program's support, three associates were involved in developing and maintaining the Atmospheric Optics Observatory (AOO) on the roof of the Research Center for Science and Technology. The AOO provides a platform for a variety of instruments to monitor the amount of energy reaching the Earth's surface throughout the day. The students also worked in the development of an LED (light-emitting diode) device to monitor the effects of haze (aerosol particles in the atmosphere), and their work was published in a scientific journal. On all of their program research, the associates have coauthored seven publications and presentations during the past year alone.

One project was conducted jointly with a historically black university in South Africa. Vista University, in Port Elizabeth, South Africa, studied the effects of atmospheric pollution on solar cell performance. This is a significant issue in South Africa where cooking fires create significant air pollution. The South African students measured these impacts using a selfpowered solar monitoring instrument made by Ascension Technology, Inc., based in Lincoln Center, Massachusetts. CAU students performed similar benchmark measurements with an identical Ascension instrument. This hands-across-the-ocean project between two historically black universities accomplished benefits beyond the technical results by encouraging cooperation and understanding between the young technical students.

PV Research Associate Robert Easley completed several publications on his work with modeling and design optimization of solar cells. For this work, he received many awards, such as a first place prize for a publication and an outstanding student poster in several competitions. $\mathrm{Mr}$. Easley has recently been accepted and will enter the PhD. Program at MIT in December 2002.

This is another school encountering contracting difficulties. The first principal investigator became involved in other projects, and a second principal investigator was identified. This led to a considerable delay in the project, and no-cost extensions of the original subcontract totaled 3 years. Nevertheless, these efforts on the part of the second principal investigator, Professor Gerald Grams, and CAU's Vice President for Research and Sponsored Programs, Dr. Kofe Bota, resulted in a successful outcome.

\section{Central State University}

The PV Associates Program at Central State University has contributed to the development of renewable energy education through the research and curriculum development of the PV associates and the guidance of its principal investigator, Dr. Clark Fuller. Central State was awarded two subcontracts, each supporting the equivalent of one associate annually. Ten undergraduate students directly participated in the program 
and received partial scholarships or work-study opportunities during the past 3 years. Four of the students have graduated, and the other six are still enrolled at the university. Seven of them completed renewable energy-related internships at research facilities or other academic institutions, including internships in Senegal and South Africa.

About one thousand high school students have benefited from the program, either through community outreach presentations at schools or through attendance at a Central State-sponsored Renewable Energy Summer Camp for high school students. Seventy-five high school students typically attended the three, 1 -week camps that have been hosted during the past 3 years.

At Central State University, a renewable energy laboratory course was developed that evolved into an advanced level course taught at Wilberforce University. As mentioned before, Wilberforce and Central State are both located in Wilberforce, Ohio. Wilberforce successfully participated in the DOE/NREL program until its principal investigator left the school in 1998. The Central State course involves hands-on design and installation of renewable energy lighting systems that use PV technology. Each student was required to develop a work plan for fall, winter, and spring quarters that incorporated renewable energy technology as a part of their major field of study (Manufacturing Engineering and Water Resources Management). The students received work-study pay as a part of their activities, including attending the renewable energy laboratory course mentioned above. The research associates were also required to interact with PV manufacturers, visit research and technology distribution sites, and become familiar with technology applications at various locations in the eastern and midwestern United States.

For more than a decade, and before receiving DOE/NREL HBCU funding, Central State University used its experience and expertise with the Northern Senegal Water Management Project (NSWMP) to form the core in developing the foundation for student training and research under programs sponsored by NREL and NASA. The NSWMP is a natural resources project in Senegal, West Africa, that is designed to develop self-sufficiency among Senegalese villagers by providing them with the expertise and materials to install and maintain their own renewable energy water-pumping systems using wind or solar energy technologies. While under the sponsorship of the DOE-NREL HBCU PV Research Associates Program, the undergraduate students who participated in the program not only learned the basics of wind and solar technology, but also focused on research into how photovoltaics can provide new and supplemental energy sources to address the critical shortage of water in many developing countries. Students had the opportunity to participate in hands-on research at many domestic locations and laboratories, as well as participate in one or two overseas projects located in South Africa or Senegal.

Central State University has entered into a collaborative agreement with Wilberforce University, the Cleveland African American Museum, and the NASA Glenn Research Center to build and sustain a program that will introduce college and high school students to PV technology through a theme of Energy Technology for Developing Countries. Funds to support this program are provided by NASA, NREL, Research Challenge, and private sources. Students spend at least one weekend a month (January through May) at various Cleveland laboratory sites performing hands-on activities that are related to renewable energy technology. 
As a result of the NREL-supported program, Central State University has been able to leverage additional funds and research opportunities for students through such entities as the Ohio Board of Regents and NASA. These additional funds total more than $\$ 435,000$.

Central State University has sought ways to expand the opportunities for NREL PV research associates by creating and participating in consortium programs that provide a variety of renewable energy program and research opportunities. The Consortium for Advancing Renewable Energy Technology (CARET) and the Student Outreach for Renewable Energy Technology consortium (SORET) are research and education programs involving five universities and the NASA Glenn Research Center. These five universities (Fisk, Wilberforce, Central State, Savannah State, and Kent State) are working together with the NASA Glenn Research Center and several business entities toward four objectives, which are geared toward (1) developing programs that promote science, technology, and engineering disciplines to secondary school students using the theme of renewable energy; (2) attracting more science, technology, and engineering students to member institutions, and encouraging their continued education through participation in CARET/SORET programs and a pipeline mechanism that facilitates transitions to other member institutions; (3) performing research in areas with the potential to advance the technology of renewable energy systems; and (4) promoting advances in the quantity and quality of utilization of renewable energy systems in our society. The consortium has developed a pipeline mechanism that actively works with students interested in these areas to manage their educational opportunities within the consortium. The consortium also works with students to develop educational programs for secondary school students.

\section{Southern University}

Southern University A\&M College (SU) received two successive DOE/NREL awards beginning in 1995. The initial intent of the project was to create interest and train the students in the utility and development of renewable energy sources and technologies, while introducing them to research methodologies for pursuing technical careers and graduate education. The first contract supported the equivalent of one associate per year, whereas the second supported two associates. For the second subcontract, SU was funded to support students in the materials research project entitled "Thin Film Electrodes and Electrolytes for Renewable Energy Sources." The project centered on low-temperature synthesis (sol-gel, gas combustion, and microwave) and characterization (XRD, DSC/TGA, impedance spectroscopy), surface science (HRTEM, STM), and X-ray absorption spectroscopy (EXAFS, XANES) of low-cost, lightweight, low-dielectric and high-specific-area materials for energy storage (primary and secondary batteries: Li, Ag, lead acid, Li-ion, and capacitors), energy conversion (direct oxidation in methanol fuel cells and solid oxide fuel cells), solar energy (photoelectrochemical cells), and environmental sensors.

On average, four PV associates presented their research results at the REAP conferences held at Southern University (Baton Rouge, Louisiana, August 1999), NREL (Denver, Colorado, August 2000), and Texas Southern University (Houston, Texas, August 2001). Six of the 15 PV associates supported through this subcontract are now employed in industry. One graduate, Tameka Page, is now employed in Carning, Inc., an engineering firm, and recently became a manager of its reliability section. Charles Wayne was selected for employment by the U.S. 
Information Agency and is posted as a mechanical engineer at a U.S. embassy. At present, Maria Appeaning and A. Astanam are pursuing, respectively, a PhD degree in Chemistry at Louisiana State University and a PhD in Science Education at Southern University. Jabari Robinson won a $\$ 5,000 /$ year award (NSBP scholarship) from DOE to complete his undergraduate education in Physics.

During this 3-year project, work was done on several new electrodes and electrolytes (nanostructured $\mathrm{LiCo}_{1-\mathrm{x}} \mathrm{Ni}_{\mathrm{x}} \mathrm{O}_{2}, \mathrm{LaSrMnO}_{3}, \mathrm{LaMnO}_{3}, \mathrm{CeO}_{2}, \mathrm{Ag}_{2} \mathrm{O}-\mathrm{SiO}_{2}, \mathrm{Li}_{2} \mathrm{O}-\mathrm{SiO}_{2}, \mathrm{TiO}_{2}, \mathrm{SnO}_{2}$, $\mathrm{InO}_{2}, \mathrm{SnInO}_{2}$, powders, glasses, and thin films) for Li-ion batteries, fuel cells, and sensors using novel gas combustion and condensation route and a pulsed-laser deposition technique. The associates at Southern University gained hands-on experience in advanced thin-film deposition techniques and use of analytical instruments for material characterization, and were involved in the fabrication of PV devices. This exposure and training enabled them to focus on pursuing graduate education.

Participation in this project helped with the development of an emerging nanoscience and nanotechnology program at Southern University. During this project, the principal investigator, Dr. Rambabu Bobba, published 16 papers in refereed journals. Of these 16, PV associates coauthored 5 papers in collaboration with staff scientists at NREL. Dr. Bobba was able to generate larger grants from Federal agencies such as the Department of Defense and the National Science Foundation (NSF). He was recognized as an "Outstanding Researcher of the Year" at Southern University, and his work has been cited in many refereed journals. Some of the SU associates were invited to present their work at two meetings (one in Hawaii and one in Greece) of the International Conference on Solid State Ionics. Tameka Page and Charles Wayne received partial travel support from the International Society of Solid State Ionics to attend these conferences.

\section{Hampton University}

Hampton's subcontracts supported two PV associates working on architectural projects. The Hampton students held summer internships for several years at NREL in support of various solar building activities. These early interns created architectural drawings that appeared on an NREL Web site. One 1996 intern, Natalie Bunkley, prepared several architectural sketches of an entrance gate for NREL's "Site Access Control Project." She developed detailed cost estimates for several gate options, and the outgrowth of her work was NREL's entrance gate at its visitor center, completed in 1998. Another intern worked at the historic Georgetown Energy Museum in Georgetown, Colorado. He prepared sketches of this historic facility, the state's oldest hydroelectric installation still producing electricity for the local utility. The architecture professors at Hampton included solar design as part of their undergraduate building design courses, thereby influencing dozens of budding architects.

The second PV research subcontract at Hampton focused on an innovative marine architecture project. The project goal was to demonstrate the applicability of photovoltaic and renewable energy technology to marine-based architecture by studying, researching, designing, and simulating a "Floating Theater." Hampton University is located in the Hampton Roads region, a region of seven municipalities whose access to the ocean, rivers, waterways, and coasts is vast. 
Hampton worked with Newport News Shipbuilding, the U.S. Army Corps of Engineers, the Defense Revitalization and Marketing Office, and the Virginia Beach International Arts Festival in developing the concept. The project uses photovoltaics and other renewable energy and conservation technologies on a facility designed for education and demonstration. It is mobile and can be used as a conference facility and visitor's attraction. Hampton PV associates and other architectural engineering students at Hampton have designed and built 20 detailed models of floating structures that could be the solar-powered floating restaurants, theatres, museums, and libraries of the future. The computer-simulated demonstration and viewing of the models were presented at the 2001 REAP Conference and Review Meeting.

\section{Howard University}

At Howard University, PV research associates have developed a research area in systems engineering to improve the quality and reliability of PV technology. The funding supported two PV research associates. The approach was to develop an artificial intelligence scheme, Artificial Neural Network (ANN) and Genetic Algorithm (GA), to predict and identify faulted PV system conditions for different conditions of solar radiation, time, and temperature. For given faulted PV modules, a GA scheme was developed to track the optimal maximum power points. The goal was to develop a control scheme using a fuzzy logic controller to achieve stable PV system operation. Finally, other students were involved in a variety of hands-on PV projects, with some leading to undergraduate theses. One of these projects developed an integrated cost-benefit analysis scheme for PV power systems. For the last three summers, Howard students have been interns at the Renewable Energy and Environmental Academy at Texas Southern University.

\section{North Carolina Central State University}

The research objective in the North Carolina Central State University (NCCU) PV Associate Program was to establish several methods to study low-temperature structural modification and characterization of photovoltaic and thermophotovoltaic semiconductors. The NCCU effort was a particularly strong fundamental research project involving undergraduates majoring in solidstate physics and materials science. Part of the project identified electro-optical properties critical to the performance of these semiconductors and established an adequate explanation of the observed behaviors of some selected solar cells, particularly amorphous-silicon cells. One of the principal aims of the task was to employ free-electron laser (FEL) capabilities in electron and vibrational excitations for Raman and high-resolution photoluminescence (PL) spectroscopy for characterization of thin films, as well as bulk samples. The FEL studies took place elsewhere, at the Jefferson National Accelerator Laboratory and at Duke University. One of their significant research results was to demonstrate the possibility of changing $\mathrm{Si}-\mathrm{H}$ bonding configuration in amorphous silicon with very low energy, FEL IR radiation, without heating the sample. By proper choice of wavelength, in the vicinity of $5 \mu \mathrm{m}$, as well as the energy density and duration of illumination, it was possible to increase the $\mathrm{Si}-\mathrm{H}$ bond ordering by simultaneously increasing the $\mathrm{Si}-\mathrm{H}$ bond concentration. Specific student thesis projects were: 
Anderson Sunda-Meya: Selective Bond Breaking in Amorphous Hydrogenated Silicon by Using Duke FEL

Christian Harris: Photoluminescence and the Theoretical, Physical Structure of a-Si:H Solar

Cells

Mariamma Kambon: Atomic Force Microscopy and the Investigation of Solar Cells

Dana M. Warren: Atomic Force Microscope Image Analysis

These PV associates graduated this year and have been accepted into graduate programs at other universities. They presented more than 10 presentations in 2001 at regional and national meetings and have one publication in a professional journal. One graduate from last year is presently in graduate school at N.C. State University. Several of the students worked as summer interns at NREL's Measurement and Characterization Division; one was invited back for 2 successive years.

\section{Program Highlights}

In the last 6 years, the program has made a significant contribution in education and outreach in the field of renewable energy at HBCUs, their local communities, and the international community. The funding provided through this program to outstanding undergraduate students (the PV research associates) for their studies did more than just encourage their knowledge of photovoltaics through research and outreach projects. The funding enabled many student associates to earn undergraduate degrees in science and engineering fields. Historically, these fields have had an alarming underrepresentation with respect to African-Americans. Many associates have chosen to go on to graduate school, and some are employed in renewable energyrelated fields. Moreover the program's benefits reached thousands of young people through the outreach efforts of the principal investigators, their staff, and the PV research associates.

A statistical summary of this program follows (see graph below)

- The number of undergraduates who benefited from the program outnumbered the selected student associates by a factor of 2 .

- The average number of publications, reports, and/or presentations was three per PV associate.

- $25 \%$ of the PV associates are continuing their education in graduate schools.

- $19 \%$ of the PV associates are employed in renewable energy-related fields.

- More than 13,000 high school, middle school, and elementary school students benefited from renewable energy camps and summer academies.

- 53 college professors and 10 graduate students participated in the program through joint research projects, student mentoring, or summer programs as instructors, administrators, or counselors.

\section{Lessons Learned}

Although the program had many successful stories in terms of student accomplishments, we have identified some areas of concern. Specifically, these are the administration of subcontracts, compensation for the principal investigators, and (always a concern) inadequate resources. For some universities, the administration of the contracts was difficult based on their inability to manage and keep the invoice process on schedule and to respond to the complexities of the 
DOE/NREL contracting process. This sometimes resulted in delays in sending funds at the designated time. The efficiency of the school's contracting and invoicing was somewhat dependent on its ability to do business at the same level and efficiency as is expected for larger institutions having more extensive resources, training, and experience. The principal investigators who mentored and motivated the students deserve much of the credit for the success of the program. However, they were not compensated for their time, because the original request for proposals asked that principal investigator funds be excluded from contract budgets. And, of course, all of the principal investigators would like to have included more students, but resources limited this.

DOE-NREL HBCU PV Research Associates Program Statistics

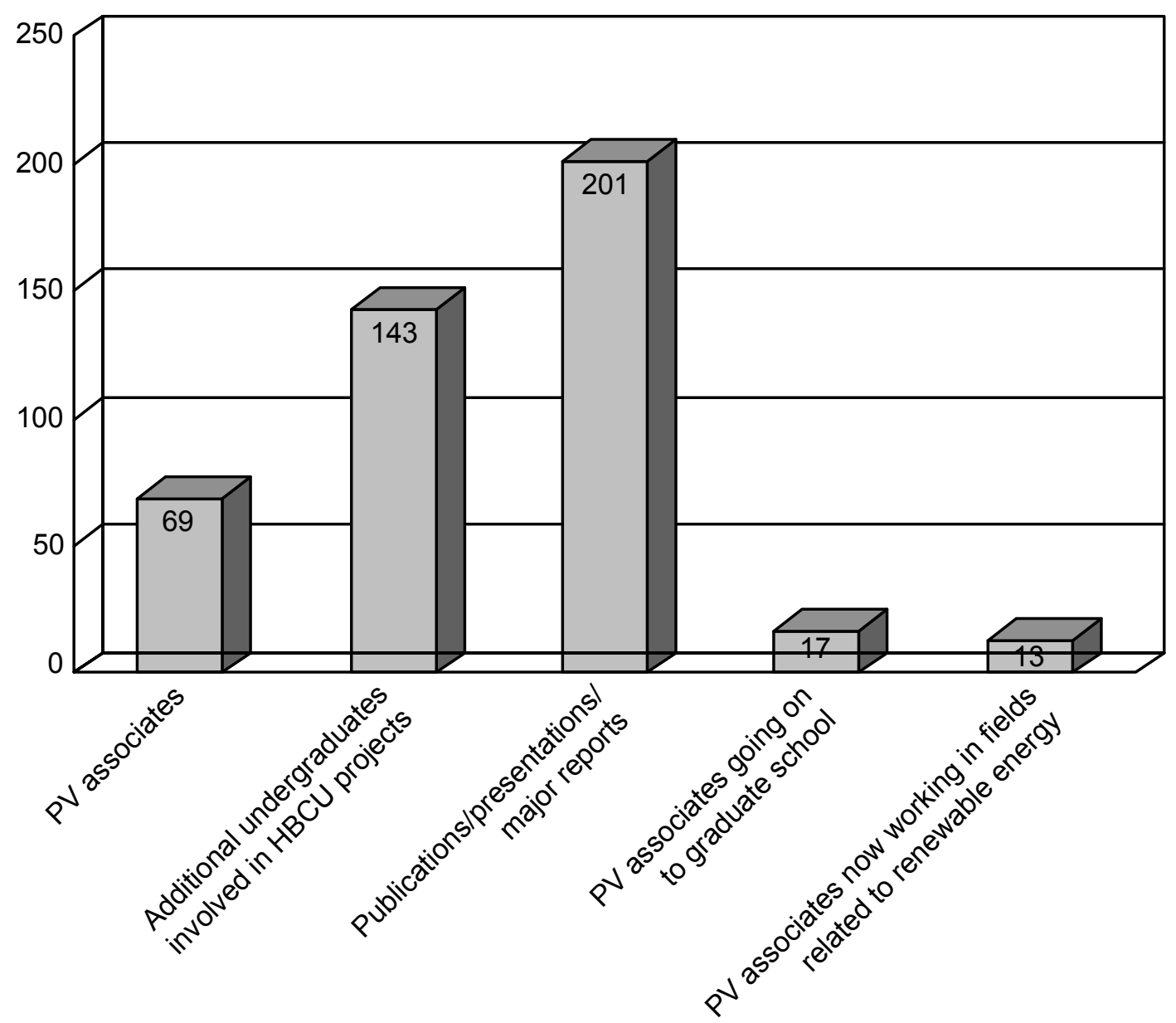

Legend: The first, second, fourth, and fifth bars are actual numbers of students affected by the HBCU Program. "PV associates" are those students who, based on outstanding performance, were selected for participation and were funded directly by the program. 


\section{Conclusions}

This small but remarkable program directly affected dozens of minority undergraduate students in ways that changed many of their lives. Indirectly, the program impacted thousands of young high school and undergraduate students as a result of many renewable energy outreach projects. The progress and accomplishments of the undergraduates were monitored and assessed through their presentations at an annual NREL-sponsored HBCU conference. Although the funding was small, typically $\$ 400,000$ per year, the money made a significant impact. The best students sometimes went on to the nation's top graduate schools (e.g., MIT) or important management positions in large companies. Other students had opportunities to learn how renewable energy can positively affect their lives and their neighbors' lives. A few were lucky enough to install photovoltaic lighting systems and water-pumping systems in Africa, and to see and feel firsthand the technical and emotional benefits of this technology for families and villages. Two of the schools, Texas Southern University and Central State University, were particularly successful in leveraging their DOE/NREL funding to obtain additional funding for expanded programs.

The DOE/NREL HBCU Photovoltaic Research Associates Program is an excellent model to replicate for other renewable energy research areas and HBCUs. By encouraging the students to be involved in DOE/NREL-sponsored PV research, we now have dozens of excellent examples of motivated and inspired students who excelled in the classroom and demonstrated commitment to the development of renewable energy. The appendix describes in detail the work done by all participants, as presented at the 2001 REAP conference.

These kinds of partnerships between government agencies and HBCUs can only enhance the development of a more diverse and competent future workforce with the potential to lead renewable energy industries and research in the upcoming years.

Because of this program's successes, we recommend a continuation and expansion of this program to include all minority-serving colleges and universities and all solar energy technologies in the DOE Office of Solar Energy Technologies. This expansion would allow Hispanic and Native American schools and students to be included along with the Historically Black Colleges and Universities. Expanding the program to other solar energy technologies will provide more solar energy project opportunities, beyond just photovoltaic projects. Even more specifically, one part of this program could help provide needed and valuable solar resource data over much of the United States through a network of minority institutions collecting such data. 


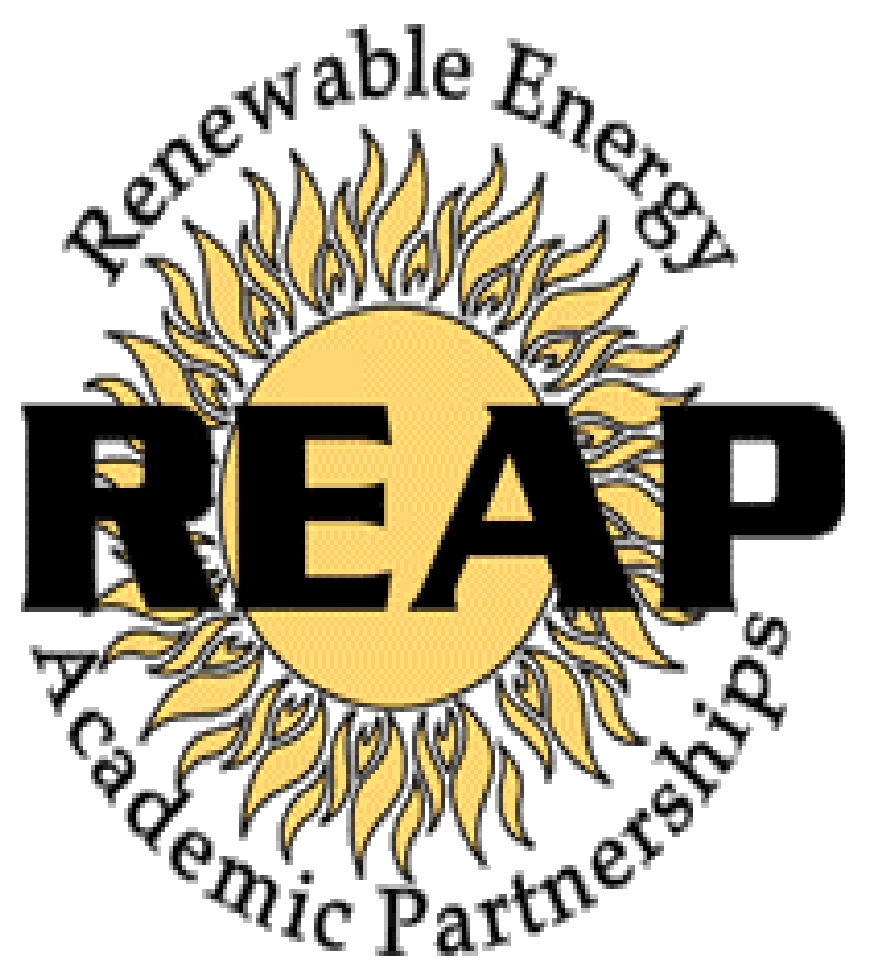

Renewable Energy Academic Partnerships (REAP) Texas Southern University

Houston, Texas

August 8-11, 2001 


\section{Contents}

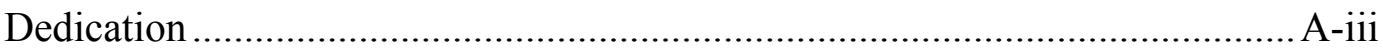

Texas Southern University............................................................................ A-

Texas Southern University Photo (Houston, Texas)............................... A-3

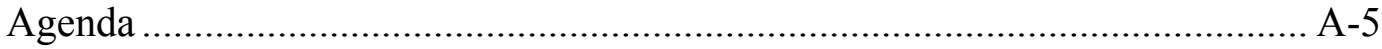

2000 Conference Photo (NREL—Golden, Colorado) ...................................... A-8

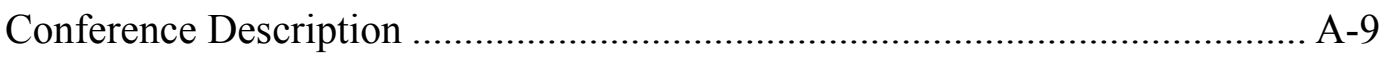

Renewable Energy Academic Partnership Panel ........................................... A-10

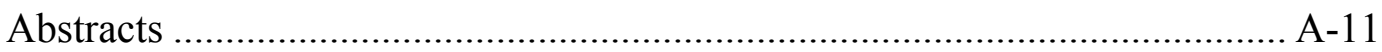

Consortium for Advancing Renewable Energy Technologies (CARET)... A-11

Central State University .............................................................. A-16

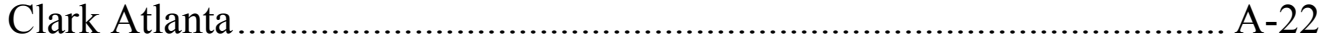

Hampton University ....................................................................... A-29

Howard University ............................................................................... A-31

Mississippi Valley State................................................................... A-34

North Carolina Central State University............................................... A-37

Southern University A\&M College ........................................................ A-42

Texas Southern University .............................................................. A-58

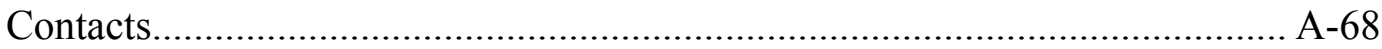




\section{IN MEMORY OF Dr. Joshua dill}

"It is good to have an end to journey toward; but it is the journey that matters, in the end."

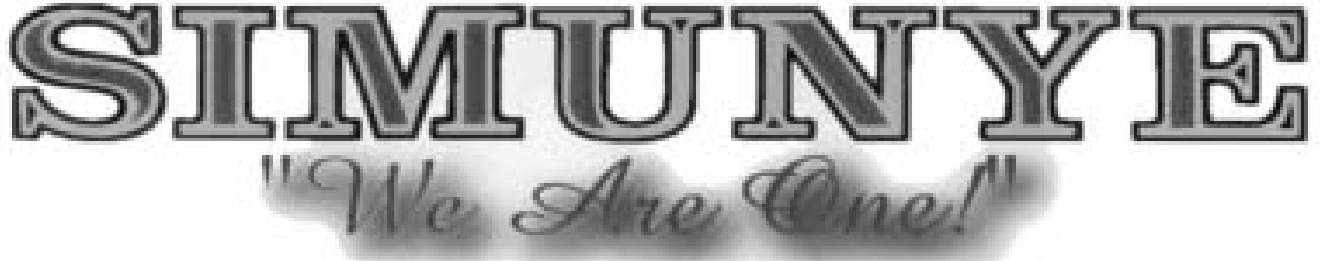

U.S. Department of Energy's National Renewable Energy Laboratory's Third Annual Renewable Energy Academic Partnership Symposium

Texas Southern University

Houston, Texas

August 8-11,2001 


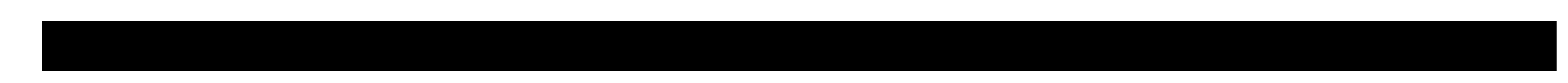




\section{Texas Southern University}

The designation of Texas Southern University as "a special purpose institution of higher education for urban programming" provides a foundation for its programming goals. Ascribing to the global implications of its urban mission, the University focuses on high quality teaching, research, and public service as a means of preparing students for leadership roles in the urban communities of our state, nation, and world. Texas Southern University offers a variety of academic programs to students of diverse backgrounds and various levels of scholastic achievement. These students matriculate in undergraduate and graduate programs leading to degrees in the arts and sciences, public affairs, education, business, health sciences, law, pharmacy, and technology.

A special challenge of the institutional mission is the open access philosophy, which affords admission to broad categories of students - from the academically underprepared to the intellectually gifted. In support of this concept, faculty develop special programs and create appropriate expected educational outcomes of all academic programs so that students will possess an appreciation for humanistic values; acquire effective use of communicative skills; and develop an appreciation and competency in the use of technology in daily living. These educational outcomes are periodically assessed to ensure the quality of the educational experience. As the result of matriculating at Texas Southern University, students gain the personal confidence and capability to succeed in the global workplace.

In fulfilling it mission and purposes, Texas Southern University is committed to the following: maintaining an innovative, productive, and receptive learning environment; implementing initiatives to ensure a suitable environment for research and other scholarly activities; and infusing new technology advances into its infrastructure and academic programs.

\section{College of Science and Technology}

The College of Science and Technology consists of the Department of Engineering Technologies, the Department of Industrial Technologies; the Department of Transportation Studies; the Department of Mathematics; the Department of Chemistry (includes pre-medical and pre-dental tracks), the Department of Biology, and the Department of Computer Science and Physics. In serving students, these units allow the College to fulfill its mission; and, through them, undergraduate and graduate degrees are offered. The undergraduate degrees are: Bachelor of Science in Engineering Technology, Bachelor of Science in Industrial Technology, Bachelor of Science in Mathematics, Bachelor of Science in Chemistry; Bachelor of Science in Physics and Bachelor of Science in Computer Science. The graduate degrees offered are the Master of Science in Biology, Master of Science in Industrial Technology and the Master of Science in Transportation Planning and Management. The Doctor of Philosophy degree in Technology Management is a consortium with Indiana State University, Bloomington. For detailed information on the graduate degrees, students are referred to the Graduate School Bulletin of Texas Southern University. 
Administratively, the College of Science and Technology is headed by a Dean who is assisted by an Associate Dean and an Assistant Dean. Each department is headed by an elected Faculty Chair who reports to the Dean.

The primary mission of the College of Science and Technology at Texas Southern University is to prepare students to be proficient in the application of basic science and technology in order for them to pursue career opportunities in various public and private sectors such as industry, government, education, and business. Students served are also capable of meeting the expanding challenges of science and technology as they complete their programs of study. Thus, the College is involved in teaching, research, and service projects as they relate to the College's mission and the mission of the University.

In pursuing its primary mission, activities focused on the academic excellence, professional service, applied research, and development allow the College to work toward the achievement of the following goals and objectives:

1. To offer high quality programs to prepare students for the scientific and technical workforce of the 21 st century,

2. To provide an environment which nurtures individual development and creativity through the application of science, engineering, and technology.

3. To prepare scientists, mathematicians, chemists and industrial technologists, engineering technologists, technical managers, and transportation specialists for careers in our society.

4. To maintain "accreditation standards" in all degree programs with heavy emphasis on applied research, development, and professional service activities.

5. To develop strong partnerships with the business, industry, and governmental sectors for economic development and technology transfer activities.

Of special note is the fact that the College is housed in two buildings with "state-of-art" laboratories, computers, and classroom facilities designed to support high-technology applications and "real-world learning experiences. It also has a group of well-qualified, dedicated faculty members who are committed to working one-on-one with students. Graduates have been and continue to be successful in entering challenging careers with a host of companies, corporations, and governmental agencies.

The College of Science and Technology is strongly dedicated to continue its commitment to academic excellence through the provision of quality education, high-technology training, developmental activities, and applied research. 


\section{Texas Southern University} Houston, Texas

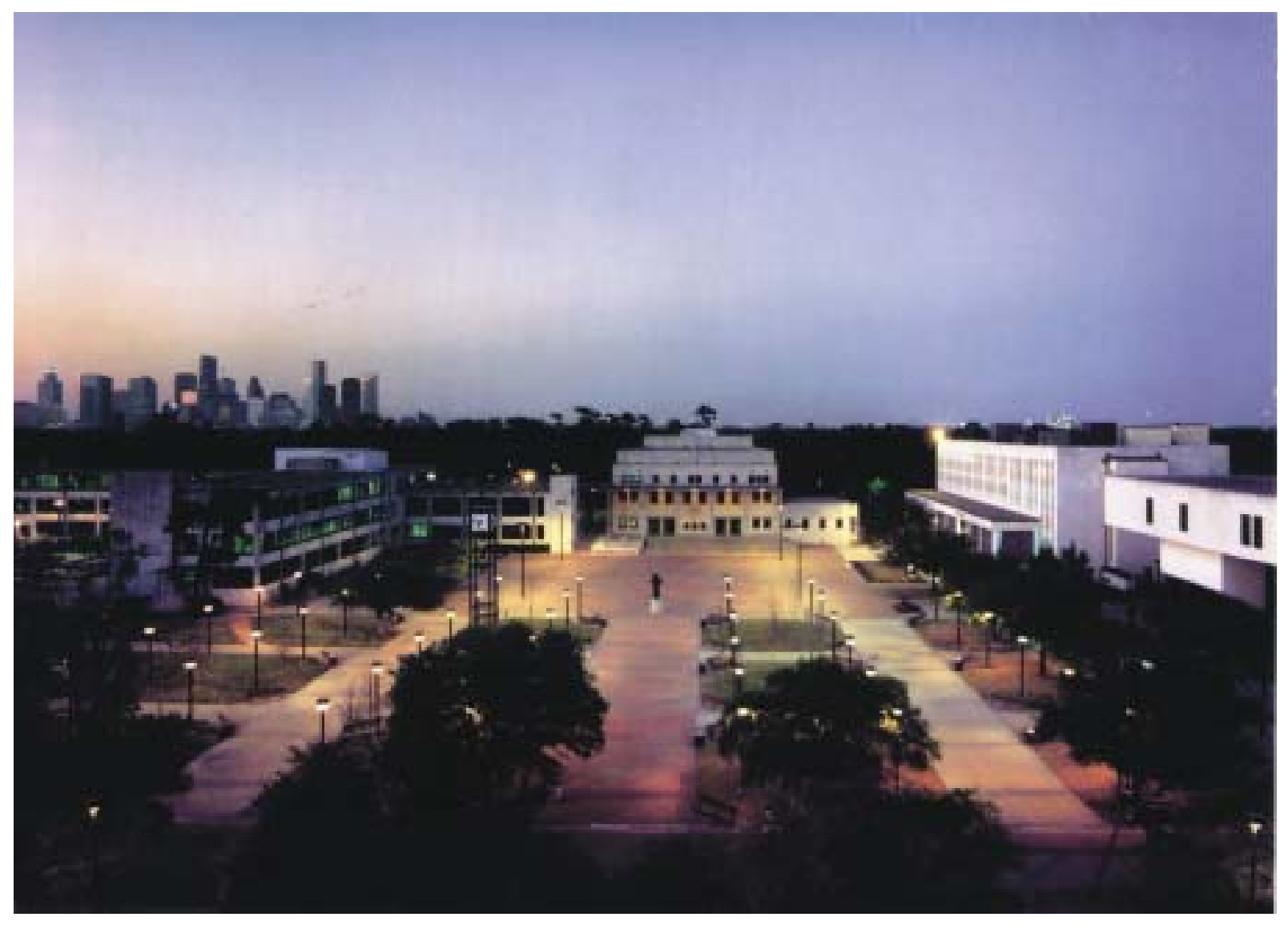




\section{(ㄱ)
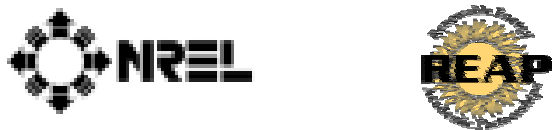 \\ U.S. Department of Energy's (DOE) \\ National Renewable Energy Laboratory (NREL) \\ Renewable Energy Academic Partnership (REAP) Symposium \\ HBCU Photovoltaics Research Associates \\ Third Annual Program Review Meeting \\ Texas Southern University \\ Houston, Texas \\ August 8-11, 2001}

Wednesday, August 8, 2001

9:00 a.m.

9:30 - 10:30 a.m.

9:30 a.m.

9:50 a.m.

9:55 a.m.

10:05 a.m.

10:10 a.m.

10:30-11:10 a.m.

11:10 a.m.

11:15 a.m. $-12: 15$ p.m.

12:15 p.m.

12:30-2:30 p.m.
Registration and Continental Breakfast - Room 225

Opening Ceremony - Moderator, Mr. Robert Easley, Moorehouse College

Welcome and Acknowledgments - Dr. Daniel C. Davis, Dean, TSU

Tribute to Dr. Joshua Hill - Mr. Oral LaFleur, TSU, and Ms. Joyce Lattimore, TSU

Remarks - Ms. Jessie Harris (NREL)

DOE/NREL HBCU Photovoltaics (PV) Research

Associates Program - Mrs. Fannie Posey Eddy (NREL)

Consortium for Advancing Renewable Energy

Technologies (CARET) Program - Ms. Maria Hill

REAP 2001 Conference Theme - TSU

PV Research Associates

\section{Tour TSU Photovoltaic Laboratories}

Break

Lunch - Technology Building Atrium

Break

Workshop on Technology Development as a Career Business Option Mr. Dennis McGee, Envirotech Corp

Mr. Marshall Little, M \& M Technology

Mr. Lawrence Union,Connecticut Energy Cooperative

2:30 p.m.

Break 


\section{Wednesday, August 8, 2001 (continued)}

2:40 - 6:00 p.m. Continue Technical Presentations - Moderator, Mr. Anthony Williams, Central State University

2:40 p.m. $\quad$ Central State University, Mr. C. Fuller, Principal Investigator

3:20 p.m. $\quad$ Howard University, Dr. James Momoh, Principal Investigator

4:10 - 6:00 p.m. Workshop on Media and Renewable Energy Houston Media Source Group

6:00 - 7:30 p.m. Reception - Technology Building Atrium

\section{Thursday, August 9, 2001}

8:45 a.m. Continental Breakfast - Room 225

9:00 am - 12:00 p.m. Continue Technical Presentations - Moderator, Mr. Rahsaan Arscott, TSU

9:00 a.m. Hampton University

Dr. Araya Asgedom, Principal Investigator

9:45 a.m. $\quad$ North Carolina Central University

Dr. J.M. Dutta, Principal Investigator

10:30 a.m. Break

10:35 a.m. Southern University

Dr. Rhambabu Bobba, Principal Investigator

11:15 a.m. $\quad$ Clark Atlanta University

Dr. G. Grams, Principal Investigator

12:00 p.m. Break

12:15 p.m. -12:45 p.m. Lunch - Technology Building Atrium

12:45 p.m. Break

1:00 - 2:30 p.m. Workshop - From Space to Earth: "The Story of Solar Electricity" Mr. John Perlin, Author

2:30 p.m. Break

2:45 - 5:45 p.m. Symposium on CARET Program

6:00 - 7:00 p.m. Reception - Technology Building Atrium 
Friday, August 10, 2001

9:15 a.m.

9:30 a.m. - 11:30 a.m.

9:30 a.m.

10:15 a.m.

11:00 a.m.

11:15 a.m.

$11: 30-12: 20$ p.m.

12:20 p.m.

1:00 p.m. - 5:30 p.m.

6:00 - 9:00 p.m.
Continental Breakfast - Room 225

Continue Technical Presentations - Moderator, Mr. Robert Easley, Moorehouse College

Texas Southern University

Mr. Oral LaFleur, Research Coordinator

Mississippi Valley State University

Mr. William Mahone, Principal Investigator

$Q \& A$

Break

Lunch

Leave TSU for NASA Tour

Tour at NASA

Dinner - President's Lounge

Sterling Student Life Center, TSU

Moderator - Mrs. Syl Morgan-Smith, NREL

Remarks - Dean Daniel Davis, TSU

Remarks and Awards - Mrs. Fannie Posey Eddy, NREL

Introduction of Speaker - Ms. Sylvia Coffie, Hampton University

Keynote Speaker - Mr. Frank Stewart, DOE NREL

\section{Saturday, August 11}

$9: 30-10: 30$ a.m.

Program Meeting (Principal Investigators only) 


\section{Golden Colorado}

\section{August 2000}

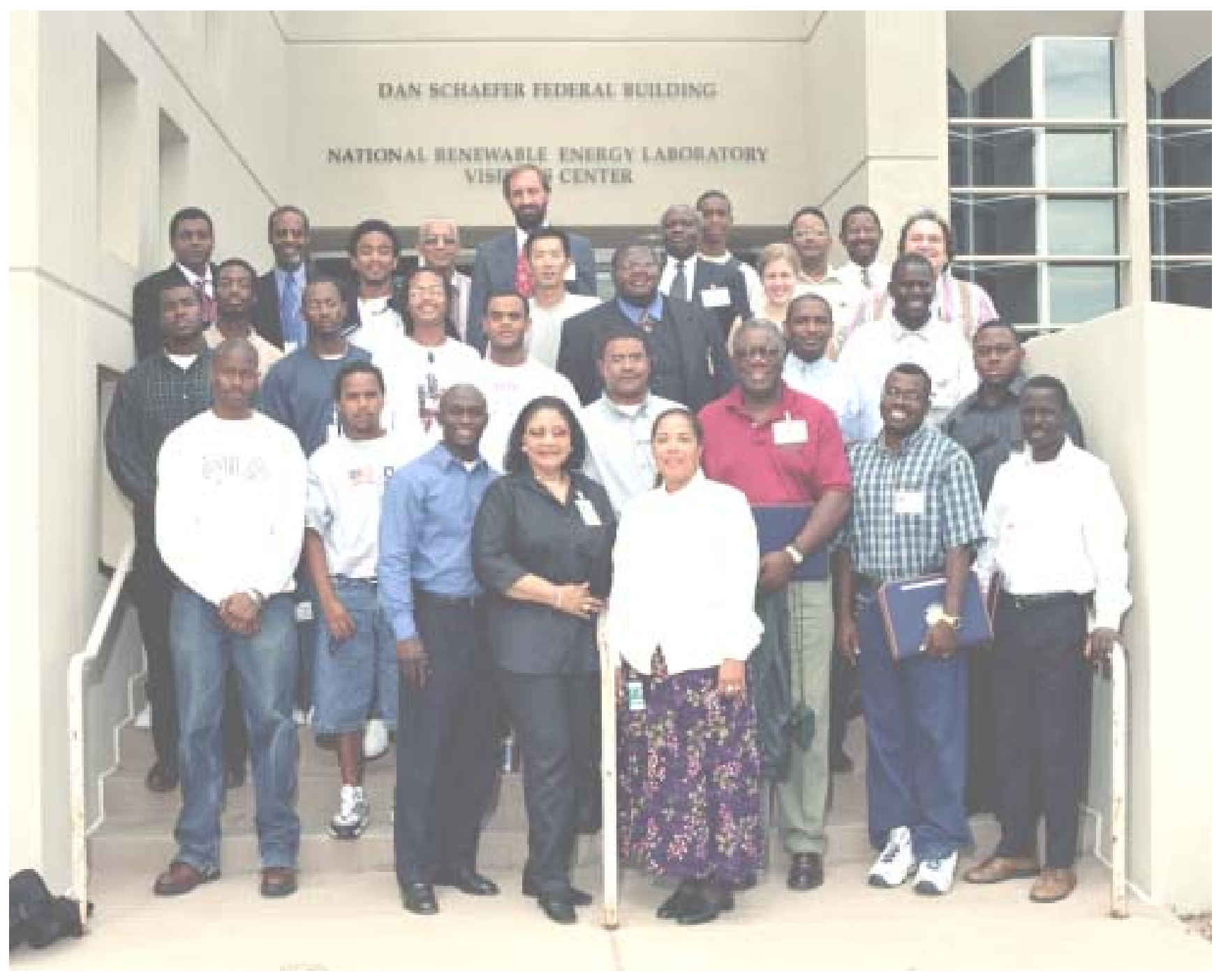




\title{
Conference Description
}

\section{History}

In 1995, the U.S. Department of Energy's (DOE) National Photovoltaics (PV) Program at the National Renewable Energy Laboratory, (NREL) in Golden, Colorado, funded eight Historically Black Colleges and Universities (HBCUs) for a period of three years, in an HBCU Photovoltaic Research Associates Program. The purpose of the program was to advance HBCU undergraduate knowledge of Photovoltaics, primarily through research investigations performed, and to encourage students to pursue careers in photovoltaics.

The eight HBCU universities selected were:

\author{
Southern University and A\&M \\ Central State \\ Clark Atlanta \\ Hampton \\ Howard \\ Mississippi Valley State \\ North Carolina Central \\ Texas Southern University
}

\section{Last Year}

The DOE/NREL Renewable Energy Academic Partnership (REAP) Conference, to review progress on the DOE/NREL funded projects at the eight HBCUs, was hosted by the National Renewable Energy Laboratory, Golden, Colorado, August 9-11, 2000. The symposium focused on NREL/DOE-funded projects at eight historically black colleges including progress made on funded projects as well as discussions about future opportunities in renewable energy.

\section{This Year}

The symposium will focus on NREL/DOE-funded projects at eight Historically Black Colleges and Universities. During the review of progress made on funded projects at each institution, undergraduates, advisors, and experts will have an opportunity to gather and discuss their research and future opportunities in the field of renewable energy. These review presentations will also provide valuable information about the role of renewable energy nationally and globally in the next millennium. In addition, a special session for the Consortium for Advancing Renewable Energy Technologies (CARET) http://www.oai.org/contact.html will be included in this year's program. 


\section{Renewable Energy Academic Partnership Panel}

\section{Technology Development as a Career Business Option}

The panel will be composed of:

- Connecticut Energy Cooperative's represented by Lawrence Union, General Manager

- Enviro-Tech represented by Dennis McGee, Founder and President

- M\&M Technology represented by Marshall T. Little, Co-Founder and President

Our goal is to provide a contemporary example of technology transfer implementation among three organizations. The panel will:

1. Provide overviews of their respective organizations

2. Discuss their approach to technology transfer collaboration, and

3. Open the discussion to the audience for questions and comments. 


\section{African Solar Village}

Qawdi Bey, Cleveland African History Museum (CARET)

\section{Program Objective}

The African Solar Village (ASV) is a unique educational program inspired by NASA Photovoltaic Test and Development Project in Tangaye, Burkina Faso West Africa during 19781984. The ASV uses the structure of a traditional African village community to describe African history and modernization. In this exhibit, the concept of the Sun is used as a tool to educate students and the general public regarding African history, geography, global energy policy and renewable energy career opportunities. Strategic integration of NASA Earth Science Enterprise science education curricular resources with the exhibit themes of Kemet as a solar culture, desertification of the Sahara/Sahel, traditional agri-astroculture farming, and modern solar Energy applications is developed for K-16 student and teacher populations. Across the past year students from Wilberforce and Central State University participated in a monthly workshop with the ASV. 


\section{Investigation into the Use of Conducting Polymers in Solar Cell Fabrication}

Adrian Calagon, Middle College for Technology Careers at Texas Southern University, Houston, Texas

Delbert Buffinger, Assoc. Professor of Chemistry, Wilberforce University, Wilberforce, Ohio (CARET)

\section{Program Objective}

Cadmium telluride based thin films can be electrochemically deposited on a number of substrates leading to the formation of low cost solar cells. Typically cadmium sulfide followed by cadmium telluride is layered onto a ITO coated glass substrate. Annealing the samples above $350{ }^{\circ} \mathrm{C}$ converts the n-type cadmium telluride to p-type forming the heterojunction. A metallic back contact completes the cell. In this report we present our investigations into the use of the conducting polymer polypyrrole as a possible substrate. Attempts were made to electrochemically deposited n-type cadmium telluride onto the polymer surface.

\section{Overall Experimental Design}

Cadmium telluride thin film solar cells are of considerable interest due to this materials near ideal band gap of $1.45 \mathrm{eV}$ and its relatively high optical absorption coefficient. Solar cell grade CdTe has been prepared by a number of different techniques[1 to 5], but electrochemical deposition provides one of the most suitable low cost methods. CdS/p-CdTe thin film devices have demonstrated efficiencies in excess of 14\%[6]. A number of substrates have been used in the production of these cells. We report our investigation into the use of the conducting polymer polypyrrole (Ppy).

Polypyrrole is easily prepared by electrochemical polymerization of pyrrole from an acetonitrile solution containing tetrabutylammonium tetrafluoroborate as the electrolyte.[7,8] The polymer grows on the working electrode (in this case a $2.0 \mathrm{~cm}^{2}$ piece of platinum foil) at a 1.1 volt potential. The counter electrode consists of a similar piece of foil and a silver wire as the reference electrode. The black film that results was then used as the substrate for our investigations.

In a typical cell, the top transparent contact acts as the substrate. Cadmium sulfide is deposited onto this layer followed by n-type cadmium telluride. An annealing step in excess of $350{ }^{\circ} \mathrm{C}$ for 10 minutes is required to convert the $\mathrm{n}$-CdTe films into p-type forming a heterojunction between $\mathrm{CdS}$ and $\mathrm{p}-\mathrm{CdTe}$ in the process.[9] A conductive metallic back layer is added to complete the cell.

By using the opaque polymer as a substrate required reversal of this process since the polymer layer would be the back contact of the cell. In the investigation, n-type cadmium telluride was electrochemically deposited onto the polymer using a three-electrode cell. Aqueous cadmium sulfate $(0.5 \mathrm{M})$ was used with $\mathrm{HTeO}_{2}{ }^{+}$produced in situ from sulfuric acid and tellurium oxide. Deposition was carried out at $90{ }^{\circ} \mathrm{C}$ and a $\mathrm{pH}$ of 2.0 at a potential of $-590 \mathrm{mV}$. 
Work is currently focused on the deposition of CdTe on the polymer. Once this is accomplished, $\mathrm{CdS}$ will be deposited onto this layer. To form $\mathrm{p}$-CdTe requires annealing above $350{ }^{\circ} \mathrm{C}$. Polypyrrole is thermally robust, but may not survive the annealing. Therefore, lower temperatures for longer periods may be required to affect this change.

1. B.J. Feldman, J.L. Boona, and T.V. Van Doren, Appl. Phys. Lett. 38, 703 (1981).

2. T.C. Anthony, A. L. Fahrenbruch, M.G. Peters, and R.H. Bube, J.Appl. Phys. 57, 500 (1985).

3. S. Chaudhri, S.K. Das, and A.K. Pal, Thin Solid Films 147, 9 (1987).

4. R.W. Birkmire, B.E. McCandles, and W.N. Sharfarman, Sol. Cells 23, 115 (1988).

5. S.K. Das and G.C. Morris, J. Appl. Phys. 72 (10), 4940 (1992).

6. P.V. Meyers and R. Birkmire, Progr. Photovoltaics: Research and Applications 3, 393 (1995).

7. G. Tourillon and F. Garnier, J. Electroanal. Chem. 135, 173 (1982).

8. P. Yildirim and Z. Kucukyavuz, Syn. Metals 95, 17 (1998).

9. B.M. Basol, J. Appl. Phys. 55 (2), 601 (1984). 


\title{
African Solar Village: Community Informal Formal Education
}

\author{
Willie Karimi (CARET)
}

\section{Program Objective}

The African Solar Village (ASV) is a community based outreach developed from a NASA exhibit on NASA's contribution to USAID developing nations energy initiative during the mid 1970 's. Interest is currently centered on NASA Glenn PV power system project at Tangaye, Burkina Faso, West Africa. A description of the ASV project to date, the outreach philosophy and future plans will be presented. National efforts to increase the participation of underrepresented populations have been in effect since the early days of the civil rights movement. An accelerated effort was launched during the 1980's due to a projected shortage of technical personnel for America's industry and security infrastructure. Given that the programs were specifically geared to increase to flow of career employees in the technical disciplines, the programs were characterized as pipeline efforts. These pipeline programs constituted pre-college enrichment activities, mentoring relationships, financial support and incentives. In addition, some of the programs are of a longitudinal basis, even extending over the K-16 grade levels. Research has shown some measure of success in the increase of diversity within a broad spectrum of disciplines and fields due to these efforts. However, a characteristic of most program is the freedom of students to opt out of the pipeline field. This can result in a significant number of students who begin a pipeline program yet do not end at the end of the pipe - within a science or technical field. With the rising cost of education some have argued that it is best to use resources for committed field interested students rather than motivational programs. Given the magnitude of the national investment in pipeline efforts there then exist a need for enhancing the retention efficiency of the pipeline. In addition, sociocultural dynamics of under representations do not disappear with an emphasis on efficiency, therefore the motivational efforts for technical career involvement must be maintained. In order to increase the flow efficiency of the pipeline more attention needs to be address to the student informal educational opportunities. Informal education integration into formal pipeline efforts can provide a non-threatening filtering of committed field interested students from the general motivational pipeline populations. This is possible due to the interest centered, self-directed provocative nature of informal institutions, particularly museums. The African Solar Village educational model is derived from the involvement learning model. This theory states that the level of academic involvement is a predictor of academic success. The more a student "participates" in a field the higher the subject specific knowledge retention. Pipeline program inherently utilizes this paradigm. The ASV extends the involvement theory to include the natural inquiry attributes of informal education settings resulting in the conversion of involvement to immersion. The formal academic environment is extended to the peer-social and community environments resulting in an increase in the retention of subject "interested" students. Pipeline retention is thus a function of subject matter immersion. Focusing on Africa, Solar Energy, Cultural Immersion and Community Service the ASV actively implements the above outreach philosophy. 


\section{Recent Progress in PPV Type Block Copolymer Photovoltaic Materials}

Sam Sun, ssun@nsu.edu, Center for Materials Research, Norfolk State University, 700 Park Avenue, Norfolk, VA 23504 (CARET)

\section{Program Objective}

In man's mission to the outer space or a remote site, the most abundant, renewable and nonpolluting external energy source is light. Photovoltaic (PV) materials can convert light into electrical power. In order to generate appreciable electrical power in space or on the earth, it is necessary to collect sunlight from large areas due to the low density of sunlight, and this would be very costly using current commercially available inorganic solar cells. Future organic or polymer-based solar cells seemed attractive due to several reasons. These include light weight, flexible shape, ultra-fast opto-electronic response time (this also makes organic PV materials attractive for developing ultra-fast photo detectors), tunability of energy band-gaps via molecular design, versatile materials synthesis and device fabrication schemes, and much lower cost on large scale industrial production. It has been predicted that nano-phase separated block copolymer systems containing electron-rich donor blocks and electron deficient acceptor blocks will facilitate the charge separation and migration due to improved electronic ultra-structure and morphology in comparison to current polymer composite photovoltaic system.

This presentation will describe our recent progress in the design, synthesis and characterization of a novel donor-bridge-acceptor block copolymer system for potential high efficient organic opto-electronic applications. Specifically, the donor block contains an electron rich alkyloxy derivatized polyphenylenevinylene, the acceptor block contains an electron withdrawing alkylsulfone derivatized polyphenylenevinylene, and the bridge block contains an electronically neutral non-conjugated aliphatic hydrocarbon chain. The key synthetic strategy includes the synthesis of each individual block first, then couple the blocks together. While the donor block helps stabilizing and transporting holes, the acceptor block helps stabilizing and transporting the electrons, the bridge block is designed to hinder the electron-hole recombination. Thus, improved charge separation is expected. In addition, charge migration will also be facilitated due to the expected nano-phase separated and highly ordered block copolymer ultra-structure. The combination of all these factors is expected to result in significant improvement of organic photovoltaic power conversion efficiency. 

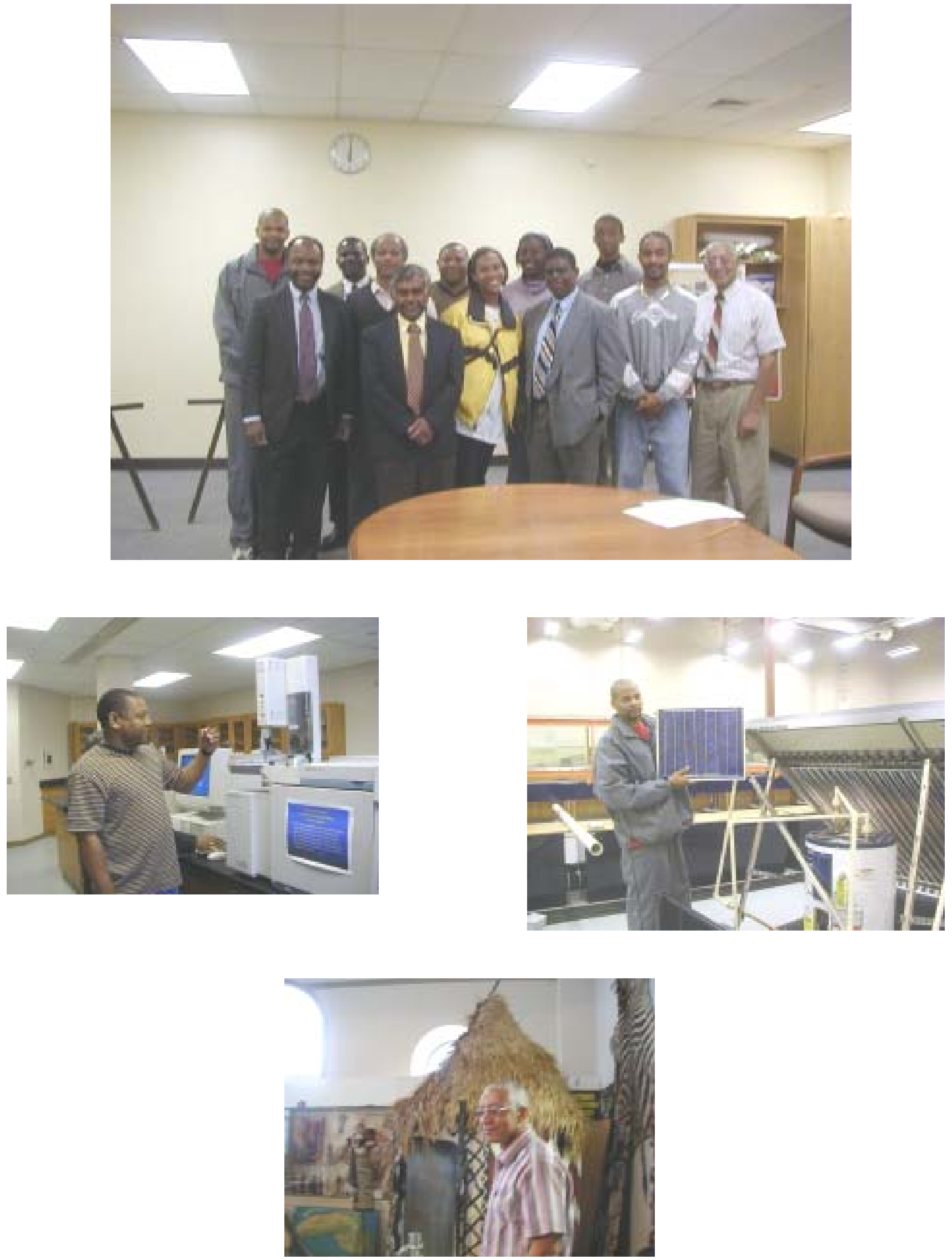


\section{The Central State University Renewable Energy Research Associates Program}

C. Fuller, G. Ndao, A. Williams, A. Gueye, Central State University, 1400 Brush Row Road, Wilberforce, Ohio 45384

\section{Program Objective}

As sponsored by the National Renewable Energy Laboratory, Golden, Colorado, the Central State University HBCU Photovoltaic Research Associates Program provides undergraduate scholarship and program support funds for the pursuit of study and research in the field of renewable energy and photovoltaics at Historically Black Colleges and Universities (HBCUs). The aim is to attract qualified sciences, engineering and business students toward pursuing a career in these areas with emphasis in photovoltaic technology.

\section{Participating Students, 2000-2001}

Charlie Hurt, Graduating Senior (2001), Water Resources/Geology

Waymond Smith, Junior, Water Resources/Marketing

Niya Curry, Junior, Water Resources

Anthony Williams, Sophomore, Manufacturing Engineering (NREL/TSU Summer Intern, 2001)

Deborah Minor, Sophomore, Biology/Pre-Med

Abby Moore, Senior, Biology/Chemistry (NASA/CAAM Summer Intern, 2001)

Aaron Jackson, Senior, Mathematics (NASA/CAAM Summer Intern, 2001)

Nitasha Hearn, Sophomore, Education NASA/CAAM Summer Intern

\section{Approach/Background}

Since the early 1990's, Central State University has utilized its experience and expertise with the "Northern Senegal Water Management Project" (NSWMP) to form the core in developing the foundation for student training and research under programs sponsored by NREL and NASA. The NSWMP is a natural resources project in Senegal, West Africa, and is designed to develop self-sufficiency among Senegalese villagers by providing them with the expertise and materiel to install and maintain their own renewable energy water pumping systems (wind and solar energy technology). While under the sponsorship of the NREL scholarship program, the undergraduate students who participate in the program not only learn the basics of wind and solar technology, but they also focus on research in ways in which photovoltaics can provide new and supplemental energy sources to address the critical shortage of water in many developing countries. Students have the opportunity to participate in hands-on research at many domestic locations and laboratories as well as participate in one or two overseas projects located in South Africa or Senegal.

\section{Integration of Complementing Programs}

Central State University has sought ways in which to expand the opportunities for NREL student research associates by creating and participating in consortium programs that provide a variety of 
renewable energy program/research opportunities. Four of these consortia arrangements are as described below.

\section{The CARET/SORET Consortium}

The Consortium for Advancing Renewable Energy Technology (CARET) and the Student Outreach for Renewable Energy Technology consortium (SORET) are research and education programs involving five universities and the NASA Glenn Research Center. These five universities (Fisk, Wilberforce, Central State, Savannah State, and Kent State Universities and the Lac Courte Oreilles Ojibwa Community College) are working together with the NASA Glenn Research Center and several business entities toward four objectives, which are:

1. To develop programs which promote science, technology, and engineering disciplines to secondary school students using the theme of renewable energy;

2. To attract more science, technology, and engineering students to member institutions and encourage their continued education through participation in CARET/SORET programs and a pipeline mechanism which facilitates transitions to other member institutions;

3. To perform fundamental research in areas with the potential to advance the technology available for renewable energy systems, and;

4. To promote advances in the quantity and quality of utilization of renewable energy systems in our society.

CARET/SORET is addressing these four objectives by involving students in the design and installation of renewable energy power and water pumping systems and involving students and postdoctoral mentors in research on materials, quantum dot phenomena, and radiation effects. The consortium is also developing a pipeline mechanism which actively works with students interested in these areas to manage their educational opportunities within the consortium and working with students to develop educational programs for secondary school students. Finally, CARET/SORET is addressing these objectives by encouraging retention by expanding the educational opportunities available to consortium students.

In the course of pursuing these objectives, CARET/SORET has developed affiliations with several additional organizations interested in working with the consortia to achieve its goals. These organizations include the Florida Solar Energy Center, the Why Not Corporation, the Grand Traverse Band of Ottawa and Chippewa Indians and Bay Mills Community College. The number of affiliate organizations continues to increase as additional educational institutions and business partners become aware of CARET capabilities.

\section{Renewable Energy Summer Camp for High School Students $(1998,1999,2000)$}

The annual Renewable Energy Summer Camp is an outreach program that is supported by Central State University, Wilberforce University, the NASA Glenn Research Center, Cleveland, Ohio and the National Renewable Energy Laboratory, Golden, Colorado. The Annual one week camp provides secondary students an opportunity to experience the basic concepts and technology affiliated with renewable energy while living within a university environment. Students view first-hand demonstrations of renewable energy 
applications as well as visit several private and governmental sites that utilize the technology.

\section{Renewable Energy Laboratory Course (Spring 2001)}

\section{Course Description}

This course is a laboratory and independent study course in applied renewable energy technology jointly conducted by Central Sate University, Wilberforce University and the Why Not Corporation. The course meets 4 hours weekly for a period of 18 weeks. Students help design and build a solar hot water system suitable for use in a home. The hot water system is instrumented so that the research intern can determine the amount of energy generated. The students also help design and build two micro-hydro-generator systems. One generator uses high pressure and relatively low flow while the other system uses low head (pressure) and high flow of water. The generator will be the same in each case so comparisons can be made between the two systems. Students meet with the instructor each week to review their progress and receive further instructions. Students are expected to work on the project between sessions with the instructor. Students are required to attend and participate in labs and the installation of the renewable energy systems, complete homework, projects, and presentations.

\section{African Solar Village Research Intern Program}

\section{Introduction}

Central State University has entered into a collaborative agreement with Wilberforce University, the Cleveland African American Museum and the NASA Glenn Research Center to build and sustain a program that will introduce college and high school students to photovoltaic technology through a theme of energy technology for Developing Countries. Funds to support the program are provided through programs obtained from NASA, NREL, Research Challenge, and private sources . Students spend at least one weekend a month (January-May) at various Cleveland laboratory sites performing hands-on activities are related to renewable energy technology.

\section{Program Description}

This project involves the study of modern science through an adaptation of the "learning environment" of a Mande Blacksmith of West Africa. The discovery and application of science within an African cultural ethos is the unique feature of the project. The daily life of a Mande Blacksmith intersects several layers of conceptual, social and natural world negotiations, tempered by the precise engineering of blacksmithing. Within this model, blacksmithing is replaced with ceramic and semiconductor production, while conceptual and social negotiations are focused upon linguistic immersion for sustainable development.

The pedagogic structure of the program is designed for one Saturday per month for five (5) months with an optional two-month individual research project. It is a twelve (12) hour learning environment, composed of four (4) sections, each with three (3) hours of technical assistance and guidance. Student will be encouraged to use section breaks to fully participate in the concurrent linguistic immersion program - "BEUTINE BA" 


\section{Workshop Descriptions:}

Kiln Operations: The basic thermodynamics of a Kiln is examined. Design parameters which effect ceramic production are isolated and quantified, such as electrical energy consumption, temperature - energy correlation and the effects of material outgassing. Students practice Kiln operation.

CDS Solar Cell: Experiment with the production of a Cadmium Sulfide solar cell within the Kiln temperature and pressure parameters. Inquiry into the physics of photovoltaic and photoconductivity. Test and evaluation of the cell characteristics. Note: CDS II is a continuation of this workshop.

Superconductors: Experiment with the production of superconducting ceramics within the Kiln temperature and pressure parameters. Test and evaluation of the ceramic materials.

Novel Products: Examination and reverse engineering of the physics and chemistry of novel low cost devices. For example, Pottery Bowls Desert Refrigeration.

Project Sun: Participation in the Martin Luther King High School and African Solar Village Project Sun Partnership. "Project Sun is part of the NASA Mission to Planet Earth effort. Project SUN is based on the development at JPL and its vendors of low cost, scientific accurate instrumentation, computer interfacing coupled with old computers as dedicated data loggers, appropriate software and curriculum, a detailed operating strategy and a system of in-service training at the school sites that will enable secondary students all over the world to contribute to the long term, time resolved, monitoring of both visible and UV solar surface radiation. Data may be transmitted to JPL via the Internet. The equipment can be used the other time for individual research projects such as investigation of the efficiency of different items of solar energy equipment, use of UV skin blockers, effects of enhanced UV radiation on plants, etc."

System Design I \& II: Fundamentals of Renewable Energy and Sustainable design. CAD designs, building codes and environmental limitations are balanced by cost benefits analysis. Sites visits of regional working designs are arranged.

Entrepreneur Science: Science and technology based business plan workshop. Student will learn what constitutes a scientific product, market identification, business structures, developing a business plan, capital sources, human organizations and product regulatory and safety compliance.

Local Installation: Installation of a small scale renewable energy system within the local Hough community.

Solar Monitoring: Participation in a derivative of the National Renewable Energy Laboratory (NREL) - HBCU Solar Monitoring Program at the African Solar Village. 
Hands On Universe: HOU participants around the world request observations from an automated telescope, download images from a large image archive, and analyze them with the aid of user-friendly image processing software. The Lawrence Hall of Science at University of California, Berkeley, is the educational center for the HOU project.

Simulations: Application and development of scientific computer simulation software with a focus on program data.

Archives: Catalog, analyze and review the archives of Developing Nations Sustainable Energy Projects, with a special focus on NASA projects.

Concurrent Cultural Program: The objective of the cultural program series is to "Africanize" the participants by creating an environment which strongly encourages speaking the languages and cultural norms. To that regard, repeat presenters will progressively increase the use of Wolof in their presentations so that by the last monthly program the presentations will be given in Wolof with English translators for new participants. This Diopian methodology can supplement exchange programs for international studies students through "immersion" technique.

The project as described above is an experimental model for future NSF, DOE, etc. grant proposals. Assessment and evaluation of its educational impact is being closely monitored for future publication. Small grants will be pursued upon team commentary on the project design. 

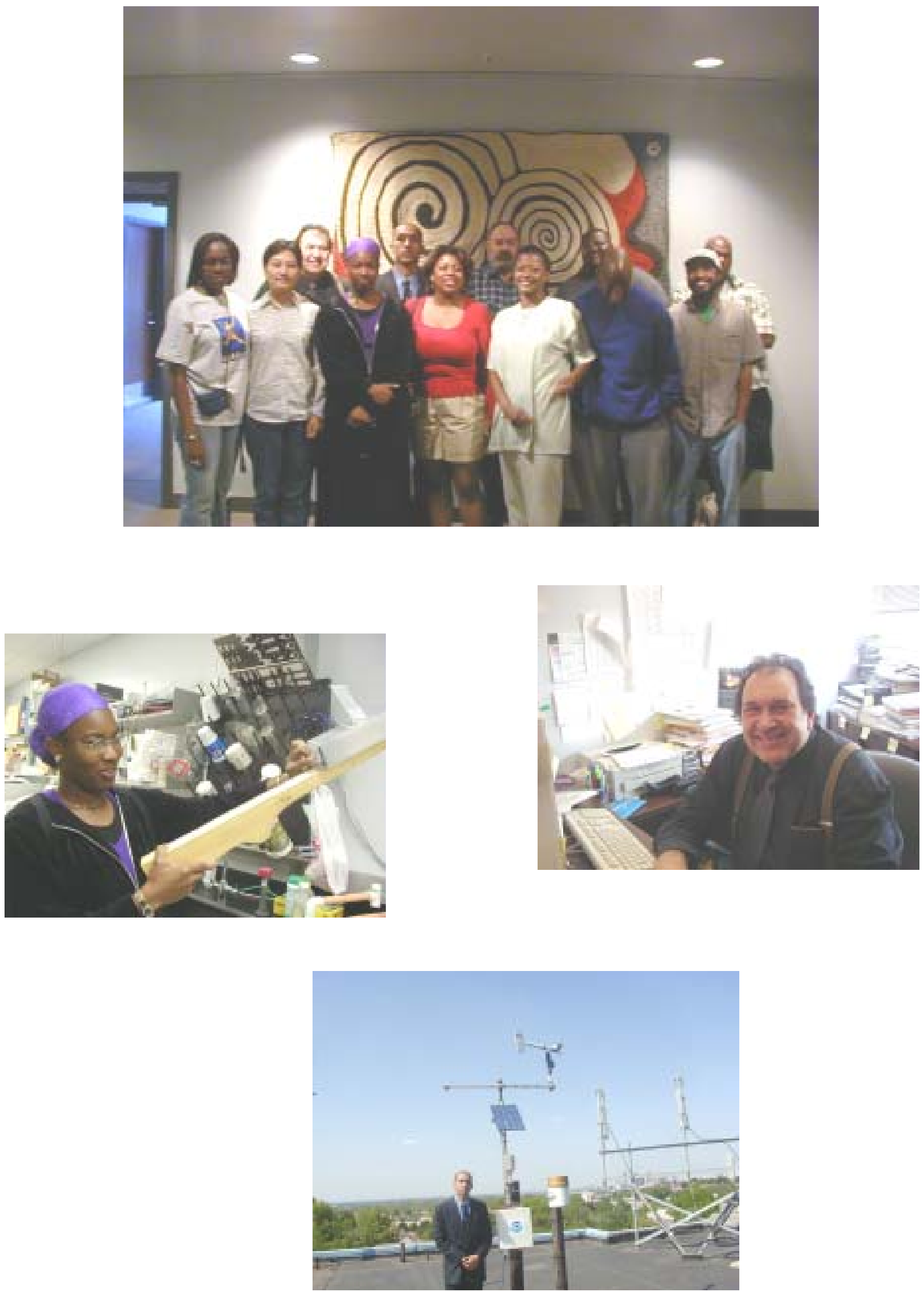


\title{
The Uncertainty Envelope Construct Applied to Direct Solar Radiation Data Quality Assessment
}

\author{
Robert Easley Jr., Clark Atlanta University
}

SERI QC labels direct and diffuse solar radiation data as good or bad by comparing the direct and diffuse measurements to the global with an uncertainty of 5\%. Using a construct I developed called an "Uncertainty Envelope," I can reduce the uncertainty and increase the accuracy of detection of incorrect or suspect direct solar radiation measurements by $50 \%$ (or, at worst, 35\%.) The Uncertainty Envelope uses the fact that the sum of the uncertainties of the Absolute Cavity Radiometer and Eppley NIP Pyrheliometer are less than the sum of the uncertainties of the pyranometers used to measure diffuse and global solar radiation. Thus, using this method, we can determine whether or not direct solar radiation data are correct or not at a higher degree of accuracy than SERI QC. 


\title{
An Overview of the HBCU Photovoltaic Research Associates Program at Clark Atlanta University
}

\author{
Gerald W. Grams and Randal L. N. Mandock, Clark Atlanta University
}

Robert L. Easley, Jr. (Morehouse College), Adwoa K. Gyekye, (Clark Atlanta University) and Ashanti Smarr (Atlanta Metropolitan College)

\section{Introduction}

This program provides financial support and research opportunities for undergraduate students to enhance their knowledge in the field of photovoltaic research and to encourage them to pursue careers in photovoltaics. A major goal of the research part of this program is to determine the effects of atmospheric variability on the production of solar energy by photovoltaic sources. Another goal is to provide our students with opportunities for obtaining a background in modeling and design optimization of solar cells.

\section{Atmospheric Effects on Production of Solar Energy}

The Earth System Science (ESS) program at Clark Atlanta University (CAU) operates an Atmospheric Optics Observatory (AOO) on the roof of the Research Center for Science and Technology. The AOO provides a platform for a variety of instruments to monitor the amount of solar energy reaching Earth's surface throughout the day. An automated weather station at the AOO site provides simultaneous data on atmospheric pressure, temperature, humidity, wind speed, and wind direction. A combination of solar radiation measurements, meteorological observations, and computer modeling work is used to carry out assessments of the efficiency of operation of photovoltaic modules under different atmospheric conditions. To improve our ability to interpret data obtained by the radiation sensors, CAU is developing a simple, inexpensive atmospheric haze sensor that uses an LED (light-emitting diode) as a narrow-band detector. Six different LED wavelengths are available, and data from such a device operated throughout the day can be used to determine the fraction of incident solar energy that has been lost due to the presence of haze (aerosol particles) in the atmosphere as a function of wavelength.

Work began on the development of the LED haze sensor during the summer of 1999 by Bryant Pierson and Akil Sutton (physics majors from Morehouse College). A working model was completed and preliminary measurements were obtained prior to the First REAP Conference in Baton Rouge, LA, in August 1999. In the following year, additional efforts were carried out to optimize the performance of the LED haze sensors and to develop the computer software required for analysis of data. Adwoa Gyekye (a CAU physics major) carried out tests and routine observations with the new sensor in Summer 2000 to evaluate the operation and accuracy of the instrument. These results were reported by Bryant Pierson at the Second REAP conference in Denver in August 2000. Ms. Gyekye joined the PV Associates program as an undergraduate research assistant in Fall 2000 to continue working with the ESS research staff on testing and evaluating the instrument as it underwent several modifications to make it simpler and easier to operate. The development work on the instrument is nearing completion, and a technical paper will be submitted for publication in a scientific journal by the end of the year. Mr. Ashanti Smarr 
from Atlanta Metropolitan College operated the instrument and worked on data analysis procedures in Summer 2000, and he will present results obtained with the device at this conference.

\section{Modeling and Design Optimization of Solar Cells}

This activity is being conducted as a collaborative project with Dr. Godfrey Augustine of the Northrop Grumman Science and Technology Center. Dr. Augustine has a background in modeling and design optimization of Indium Phosphide solar cells, and he volunteered to mentor one of our students for the project. Mr. Robert Easley, a Physics and Mathematics major from Morehouse College began working with Dr. Augustine during the Fall 1999 semester. A research effort was initiated to carry out literature searches and to update an existing model for optimizing the design of InP solar cells for higher efficiency and greater radiation tolerance. The PC-1D computer program was purchased from the Photovoltaics Special Research Centre at the University of New South Wales in Sydney, Australia. This program solves the fully coupled nonlinear equations for the quasi-one-dimensional transport of electrons and holes in crystalline semiconductor devices, with emphasis on photovoltaic devices. The program was installed on a computer in our laboratory, and Mr. Easley worked with the program under the guidance of Dr. Augustine. Mr. Easley was able to continue this work while serving as an intern at NREL during Summer 2000, and results of his work on this project were described at NREL's Second REAP Conference in Denver in August 2000. During the past year, he continued using the PC-1D program to carry out systematic studies to examine changes in the maximum power output of InP solar cells. He served again as an intern at NREL during the past summer, and he will present results of his research at this conference.

\section{Conclusions and Future Plans}

Our students completed a considerable amount of research in the past year, and the enthusiasm that they acquired from obtaining the results has added a new feature to their activities speaking and presenting posters describing their research projects to other students at other universities and organizations. A partial list of some of their activities is included below. These activities serve to introduce students not directly supported by the PV Associates program to the field of photovoltaic research and thereby encourage those students to pursue careers in photovoltaics. The research projects will continue with increased levels of observation and analysis. A Multi-Filter Rotating Shadowband Radiometer (MFRSR) will be added to the CAU rooftop AOO facility. Data from the haze sensor and the MFRSR will be used as additional inputs for computer models designed to carry out an assessment of the efficiency of operation of photovoltaic modules under different atmospheric conditions. As the work carried out by the students in our program continues, their research efforts are expected to attract the attention of others students who, in turn, may also be encouraged to pursue careers in photovoltaics.

\section{PV Associates Presentations during the Past Year}

Easley, Robert L. Jr., "Modeling the Performance of InP Solar Cells," NREL Renewable Energy and Academic Partnerships (REAP) Conference, August 9 - 11, 2000, Golden, CO. 
Easley, Robert L. Jr., "Modeling the Performance of Indium Phosphide Solar Cells," Poster

Presentation, Morehouse First Annual Science and Mathematics Research Exhibition, Sept. 7, 2000, Atlanta, GA.

Easley, Robert L. Jr., "Modeling the Performance of Indium Phosphide Solar Cells," Poster

Presentation, Tuskegee First Annual Science Research Exhibition, October 14, 2000,

Tuskegee, AL. Received first prize in the Aerospace Engineering, Mechanical Engineering, and Physics Division at the Exhibition.

Gyekye, Adwoa K., "Using the Sun Photometer to Determine Extinction due to Aerosols and Water Vapor," Oral and Poster Presentations, Research Experiences for Undergraduates in Earth System Science at Clark Atlanta University, July 28, 2000, Atlanta, GA.

Gyekye, Adwoa K., "Determination of the Optical Effects of Atmospheric Aerosols using Sun Photometers", Poster Presentation, NOAA Conference on Expanding Opportunities in Oceanic and Atmospheric Sciences, Jackson, MS, 1-3 April, 2001.

Gyekye, Adwoa K., G. W. Grams, R. L. N. Mandock, B. R. Pierson, and M. L. Blyler, "Measurements of the Total Atmospheric Extinction due to Atmospheric Aerosols and Water Vapor using Multiple-Wavelength Sun Photometer Observations", Poster Presentation, NOAA CIRE (Collaborative to Integrate Research and Education) Symposium, Bowie State University, Bowie, MD, May 4, 2001

Smarr, Ashanti, "Using Multiple-Wavelength Sun Photometer Observations to Determine Extinction due to Aerosols and Water Vapor," Oral and Poster Presentations, Research Experiences for Undergraduates in Earth System Science at Clark Atlanta University, July 28, 2001, Atlanta, GA.

Pierson, Bryant R., “Atmospheric effects on production of solar energy," Second REAP Conference, August 9 - 11, 2000, Golden, CO. 


\title{
Using Multiple-Wavelength Sun Photometer Observations to Determine the Effects of Atmospheric Variability on the Production of Solar Energy by Photovoltaic Devices
}

\author{
Ashanti Smarr, Atlanta Metropolitan College; Adwoa K. Gyekye, Bryant R. Pierson, \\ Gerald W. Grams, and Randal L. N. Mandock, Clark Atlanta University
}

\section{Introduction}

The Clark Atlanta University (CAU) Historically Black Colleges and Universities (HBCU) Photovoltaic Research Associates Program provides financial support and research opportunities for undergraduate students to enhance the student's knowledge in the field of photovoltaic research and to encourage them to pursue careers in photovoltaics. One objective of the research part of this program is to determine the effects of atmospheric variability on the production of solar energy by photovoltaic sources.

\section{Development of a Multi-Wavelength Sun Photometer}

Research on the effects of the atmosphere on the amount of solar energy transmitted to the surface is carried out by CAU's Earth System Science (ESS) program. As part of the ESS research, education and outreach program, an Atmospheric Optics Observatory is operated on the roof of the CAU Research Center for Science and Technology. This observing facility provides a platform for instruments used to monitor the amount of solar energy reaching Earth's surface throughout the day. An Ascension Technology RSP (Rotating Shadowband Pyranometer) measures the global, direct, and diffuse radiation at the surface for visible wavelengths. In addition, a NOAA automated weather station operated at the observing site provides meteorological data on atmospheric pressure, temperature, humidity, wind speed, and wind direction. The ultimate goal of this project is to be able to model the effects of atmospheric haze (aerosol particles) and water vapor variations on the total amount of energy from the sun that reaches the surface.

To improve our ability to interpret data obtained by the RSP and the meteorological instruments, CAU is a developing a simple, inexpensive atmospheric haze sensor that uses an LED (lightemitting diode) as a narrow-band detector. Six different LED wavelengths are available, and data from such a device operated throughout the day at multiple wavelengths can be used to determine the fraction of incident solar energy that has been lost due to the total amount of haze and water vapor in the atmosphere. Sun photometers have been built and operated for each of the different LED wavelengths. The sun photometer measurements are analyzed by plotting the natural logarithm of the solar radiances measured with the photometer versus the secant of the zenith angle of the sun at the time of each observation (Langley plots). The optical thickness of the atmosphere is obtained by measuring the slope of the plotted line. Results obtained for photometer observations at multiple wavelengths in the Atlanta metropolitan area will be presented. 


\section{Future Plans}

A Multi-Filter Rotating Shadowband Radiometer (MFRSR) has been purchased with funds from other projects to be installed as part of CAU's rooftop AOO facility. Data from the haze sensor and the MFRSR will be used as additional input for computer models designed to assess the efficiency of operation of photovoltaic modules under different atmospheric conditions.

\section{Sun Photometer Presentations during the Past Year}

Gyekye, Adwoa K., "Using the Sun Photometer to Determine Extinction due to Aerosols and Water Vapor," Oral and Poster Presentations, Research Experiences for Undergraduates in Earth System Science at Clark Atlanta University, July 28, 2000, Atlanta, Georgia.

Gyekye, Adwoa K., "Determination of the Optical Effects of Atmospheric Aerosols using Sun Photometers", Poster Presentation, NOAA Conference on Expanding Opportunities in Oceanic and Atmospheric Sciences, Jackson, MS, 1-3 April, 2001.

Gyekye, Adwoa K., G. W. Grams, R. L. N. Mandock, B. R. Pierson, and M. L. Blyler, "Measurements of the Total Atmospheric Extinction due to Atmospheric Aerosols and Water Vapor using Multiple-Wavelength Sun Photometer Observations", Poster Presentation, NOAA CIRE (Collaborative to Integrate Research and Education) Symposium, Bowie State University, Bowie, MD, May 4, 2001

Smarr, Ashanti, "Using Multiple-Wavelength Sun Photometer Observations to Determine Extinction due to Aerosols and Water Vapor," Oral and Poster Presentations, Research Experiences for Undergraduates in Earth System Science at Clark Atlanta University, July 27, 2001, Atlanta, Georgia.

Pierson, Bryant R., “Atmospheric effects on production of solar energy,” NREL Renewable Energy and Academic Partnerships (REAP) Conference, August 9 - 11, 2000, Golden, Colorado. 

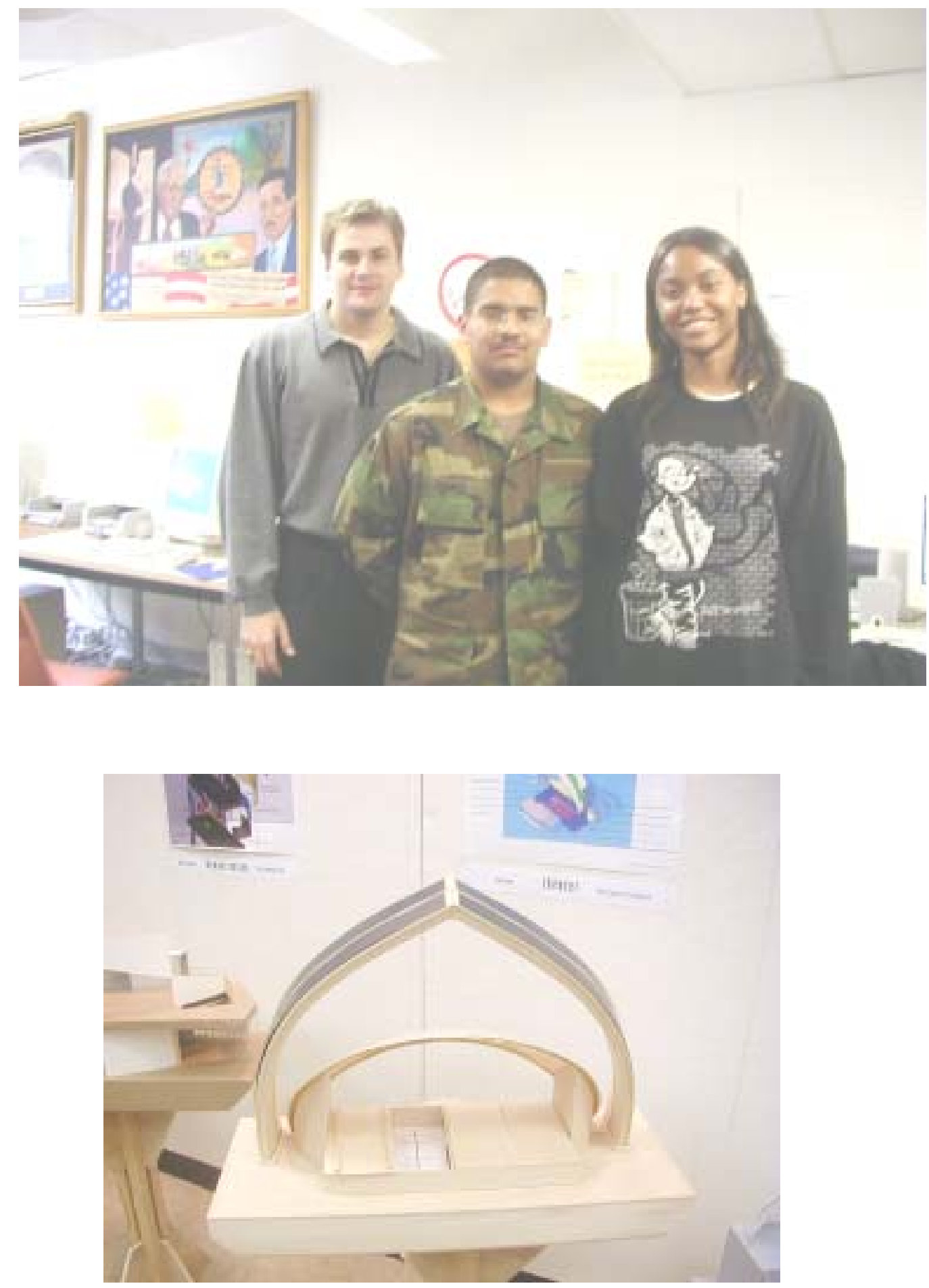


\section{Solar African Village}

Sylvia Cofffie, Hampton University

\section{Program Objective}

An African solar village will be constructed on the campus of Texas Southern University for demonstrating the practical usage of solar energy in rural communities of South Africa. This paper highlights the design and modeling of the African solar village.

In designing the village as a demonstration area, having a close community feeling was a task to achieve as intern architecture major. This was achieved by designing a linear village where all the huts are arranged in rows. It also exudes a controlled atmosphere when different groups of students tour the village, due to the size of the lot allocated to each hut on the site. In the modeling of this village, earth clay was the main material used as is most commonly used in the building of the huts in the rural area of South Africa.

The overall idea of this African solar village is to demonstrate and to educate our future leaders on the advantages of conserving energy and how best to use solar energy to generate electricity to underdeveloped countries. 


\section{Howard University \\ Washington, DC}
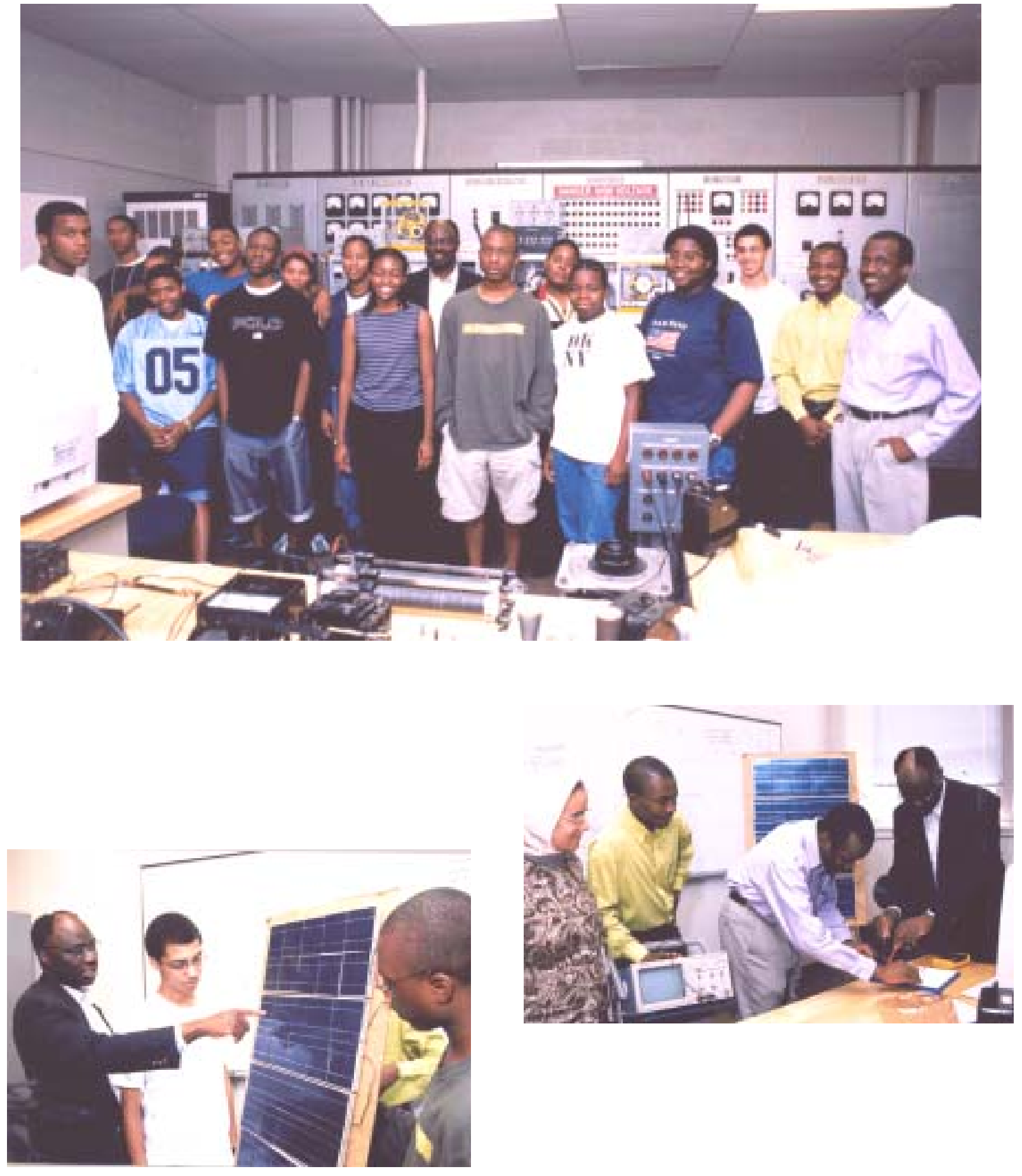


\section{Solar Powered Battery Charging Station}

Mark Agada, Howard University, Department of Electrical Engineering, Washington, DC 20059

\section{Program Objective}

This project is directed at understanding the need for solar battery charging in rural communities. The aim is to investigate the performance of a solar powered battery charger under conditions in Houston, Texas for comparison in South Africa.

The battery charging station consists of a solar panel, voltage regulator and several deep cycle batteries. It is arranged to provide a direct current at the maximum rate that the batteries can handle until the voltage rises to near $80-90 \%$ full charge level. The regulator provides control for the voltage applied to the battery for protection against overcharging. This paper will show results of tests that have been conducted to determine the following characteristics:

1. Charging current

2. Charge time

3. Effect of temperature

4. Effect of solar irradiance

5. Effect of tilt angle on battery charging station. 


\section{Tracking, Control and Distribution Reliability of an Integrated Photovoltaic (PV) System}

James A. Momoh; Peter Bofah; Abdul R. Ofoli, Howard University, Washington DC 20059, Department of Electrical Engineering, Center for Energy Systems and Control (CESaC)

\section{Program Objective}

The Center for Energy Systems and Control (CESaC) at Howard University is developing an integrated training and control scheme for PV system under different operating conditions. The scheme exploits Genetic Algorithm (GA) for maximum power tracking and incorporated Artificial Neural Network (ANN) for solar radiation forecasting. Due to the vulnerability/instability of the faulted PV system, Fuzzy Logic control is developed to stabilize the system under these conditions. The Fuzzy Logic control provides an optimal adjustment on power or battery state of charge to assure adequate supply to meet a given load. To validate the capability of the re-configured system, reliability assessment is done using indices such as System Average Interruption Frequency Index (SAIFI), Expected Unserved Energy (EUE) etc. The scheme developed can be used for in-house or domestic mounted PV cells for operational purposes.

As part of the training program, undergraduate and graduate students are participants of the research work at Howard. In addition, an outreach program targeted for fifteen (15) High School Students from Washington Metropolitan Area, Texas and Minneapolis, California, are involved in development of hands-on projects in PV system for monitoring and display in public buildings. The exposure in PV technology at Howard has helped to develop research and training programs in renewable energy resources using systems engineering concepts. Some of the research work has been published in different IEEE proceedings and journals. Future work is to assess Cost Benefit Analysis of PV and controls options to enhance the deployment of PV technology for a future utility environment. 


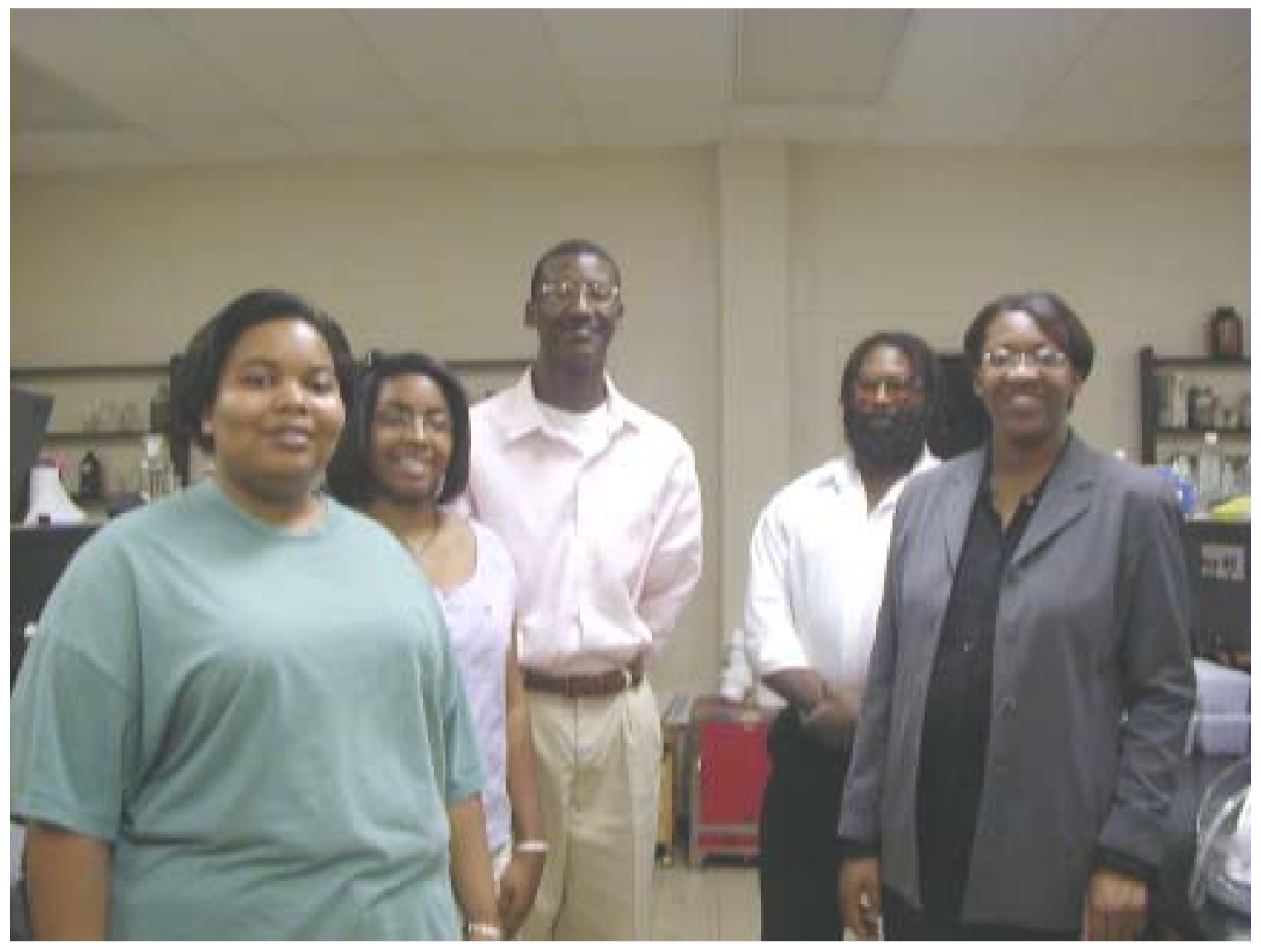




\title{
Results of Solar Power Studies in the Mississippi Delta
}

\author{
Bettina Adams, Tahida Pierre, William C. Mahone, Mississippi Valley State University, \\ Department of Natural Sciences, 14000 Highway 82 West, Itta Bena, MS 38941
}

Students and researchers at Mississippi Valley State University have been carrying out a series of research investigations designed to develop an understanding of the solar intensity profile in the Mississippi Delta and how it changes with the seasons. Other studies involved measurements with conventional solar panels. These studies provided a direct estimate of possible energy generation. Additionally solar panels were used to drive zinc electro-deposition processes. These studies showed conclusively that alternative energy can be used to drive energy storage reactions, since metallic zinc is one of the most popular active elements of most commonly used dry cells as well as the newer zinc air cells which are gaining in popularity due to high output for low surface area and volume. These studies provided much insight into the ways that solar energy systems need to be implemented.

Recent price hikes in gasoline and fuel oil underscores the need to develop alternative renewable energy sources. These sources may prove cheaper to implement, which along with deregulation procedures may allow the small businessman to gain a foothold in the energy market. To make solar energy systems feasible we must understand every aspect of solar energy production, storage and retrieval. To understand solar energy generation we must understand (1) the solar radiation intensity profile and (2) the response mechanism for solar energy voltaic cells.

Ideally the response profile should mirror the solar intensity versus wavelength profile. We have performed a preliminary long-term study of the aspects of the solar intensity profile, which produced some unexpected results. The solar radiation experiments involved using wide band photon sensors in three different orientations. One was approximately nine inches inside a cylindrical well which shielded it from diffuse radiation. Another was shielded from direct solar radiation by a semicircular band approximately four inches wide. A third sensor was open to both diffuse and direct radiation. Radiation reaching this sensor was called global radiation. Since global radiation contains both the diffuse and direct component, one expects that the sensor exposed to global radiation should give a response equal to the sum of the sensor response from the other two sensors. The conclusion we reached after two years of observation was as follows. The global mode response was equal to the sum of the direct plus diffuse response only at noon during the height of the summer solstice. Most of the other time the direct response is larger up to $50 \%$ larger in some instances. Atmospheric scattering could not explain this observation. Therefore we concluded that somehow the direct component was being scattered by the diffuse component at the surface of the detector. This data indicates that solar power output can be increased by nearly $50 \%$ by using an optical concentrator which would not simply eliminate the diffuse component but will also add to the direct component. This is because the diffuse component is redirected as it is focused toward the surface of the detector. Another piece of information learned from the solar radiation experiments was that cloud cover is a crucial factor in determining the feasibility of solar power. Some places have nearly three hundred days of cloud cover per year. Even small clouds can have a significant impact on available solar energy at the surface, while deep cover cloud systems can eliminate all solar power output for weeks. This factor must be considered carefully in reference to any particular application. 
We also performed solar cell power output measurements over a two-year period. These measurements also turned up some surprising results. These experiments with the solar panel consisted of measuring its open circuit voltage and closed circuit current in several orientations relative to the sun and under various weather conditions. We measured the power output of the panel at a vector optimal to solar incidence for the time of the measurement and compared it to measurements with the panel set at optimal for high noon in mid summer. Here again we found that depending on the time of day or year we could achieve from $50 \%$ to $100 \%$ increase in power in some cases. Also contrary to popular conception, tests with normal silicon based solar energy cells showed that they could produce up to $40 \%$ more power at the winter solstice than at the summer solstice. We believe that this behavior is due to the behavior of free electrons in the semi conductor. The result is that a cold panel will produce more current at a high voltage than a hot panel.

A third series of experiments were designed to electro-deposit active metals from aqueous solution using solar panels as an electrical source. Most active metals are produced using a downs cell. Commercial downs cells are expensive to build and to operate. They require modification before application to the relatively low energy solar systems. Electro-deposition from slurry is an alternative that is rapidly supplanting the downs cell. Using a basic buffer solution a student researcher found that he could electro-deposit zinc which had been used in a hydrogen generation experiment. The deposited zinc was again used in the hydrogen generating reaction demonstrating the recycling potential.

In future work we will construct a rotating platform and continue the solar radiation/solar panel experiments. We also will do research into special applications like running well pumps, irrigation systems, and catfish pond oxygenating systems. These are things important to our region and can find immediate application once demonstrated. 


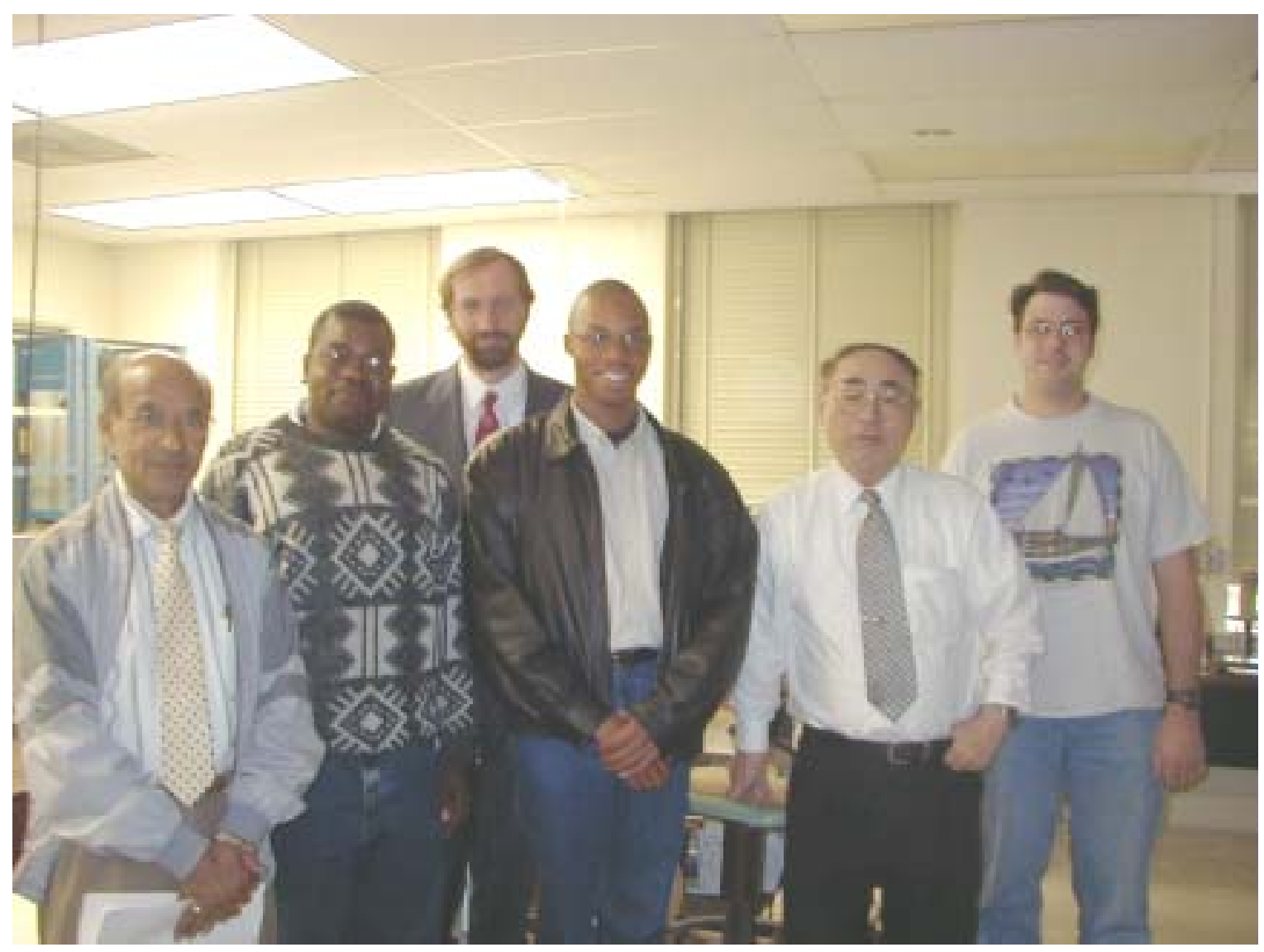




\section{Investigation of Photovoltaic and Thermophotovoltaic Semiconductors}

Jyotsna M. Dutta, North Carolina Central University

\section{Program Objective}

Our research objective is to establish several methods to study low temperature structural modification and characterization of photovoltaic and thermophotovoltaic semiconductors. One of the principal aims of the task is to employ Free Electron Laser (FEL) capabilities in electron and vibrational excitations for Raman and high-resolution photoluminescence (PL) spectroscopy for characterization of thin films, as well as bulk samples. We demonstrated the possibility of changing Si-H bonding configuration with very low energy of FEL IR radiation. Structural properties of thin films are analyzed by SAXS and IR spectroscopy, and surface morphology of various solar samples are investigated by Atomic Force Microscope (AFM). Results of these studies will be presented. 


\section{Atomic Force Microscopy and the Investigation of Solar Cells}

Mariamma A. Kambon, North Carolina Central University

\section{Program Objective}

It is well known that $\mathrm{CdCl}_{2}$ /heat treatment is essential in the production of highefficiency $\mathrm{CdTe} / \mathrm{CdS}$ solar cells. However, the ideal conditions have not yet been determined. This experiment was part of the continuing study of this type of treatment on $\mathrm{CdTe} / \mathrm{CdS}$ cells. The basic principles behind scanning probe microscopy were studied. Solar cell samples of composition: $\mathrm{CdTe} / \mathrm{CdS} / \mathrm{SnO}_{2} /$ glass were studied. The samples were treated with heat and $\mathrm{CdCl}_{2}$ vapor to investigate the importance of $\mathrm{CdCl}_{2}$ in the heat treatment of solar cells. One sample was treated with $\mathrm{CdCl}_{2}$ vapor at $430^{\circ} \mathrm{C}$ for five minutes. This lead to recrystallization. Another sample of identical composition, used as a control, was heated at $430^{\circ} \mathrm{C}$ without $\mathrm{CdCl}_{2}$. The samples were analyzed with the AFM before and after treatment. The two available techniques, contact mode and non -contact mode, were used for imaging. 


\title{
Selective Bond Breaking in Amorphous Hydrogenated Silicon by Using Duke FEL
}

\author{
Anderson Sunda Meya, North Carolina Central State University \\ In order to study the possibility of influencing the phase containing predominantly Si-H \\ bonds, while having minimal influence on the surrounding material, samples of a-Si were \\ exposed to Duke-FEL Mark III radiation. The wavelength of the radiation was selected to \\ fit the absorption maximum of stretching vibrations of $\mathrm{Si}-\mathrm{H}$ bonds $(5 \mathrm{~mm})$. By varying \\ the wavelength in the vicinity of $5 \mathrm{~mm}$, the illumination time and the power density, \\ different types and degrees of structural ordering, of Si-H bonds and $\mathrm{Si}-\mathrm{Si}$ bonds were \\ obtained, and monitored by Raman spectroscopy. By increasing the energy density, at \\ certain level the crystallization occurs. We were able to demonstrate a direct correlation \\ between short and intermediate range ordering and the wavelength and intensity of the \\ radiation. Using $5 \mathrm{~mm}$ at $10 \mathrm{~kW} / \mathrm{cm}^{2}$ leads to increase in structural disordering. However, \\ increasing power to $60 \mathrm{~kW} / \mathrm{cm}^{2}$ improves both short and intermediate order in a-Si:H, as \\ demonstrated by Raman spectroscopy. Further increasing power density by an order of \\ magnitude results in crystallization of the sample.
}




\section{Atomic Force Microscope Image Analysis}

\section{Dana Maurice Warren, North Carolina Central State University}

In contemporary photovoltaic research, nanoscale surface characterization plays an important role in the analysis of solar cell materials. Scanning Probe Microscopes (SPMs) such as the Atomic Force Microscope (AFM) is one of the high-resolution instruments that can provide valuable data that can be used in the characterization of semi-conducting materials. The data from these microscopes can then be used to provide a quantitative description of the degree of roughness of the sample or it can be used to provide a qualitative description by inspection. In the quantitative description of the surface, one of the most important parameters used to describe the surface is root-mean square (rms) roughness. Another parameter, known as the twodimensional discrete correlation function provides a correlation between all points on the surface of the sample. When paired, these two parameters provide enough information to describe the topography of any sample. In addition, the AFM can also be used to evaluate experimental processes and their effects on the topography of the sample. Some preliminary results and images will be presented. 


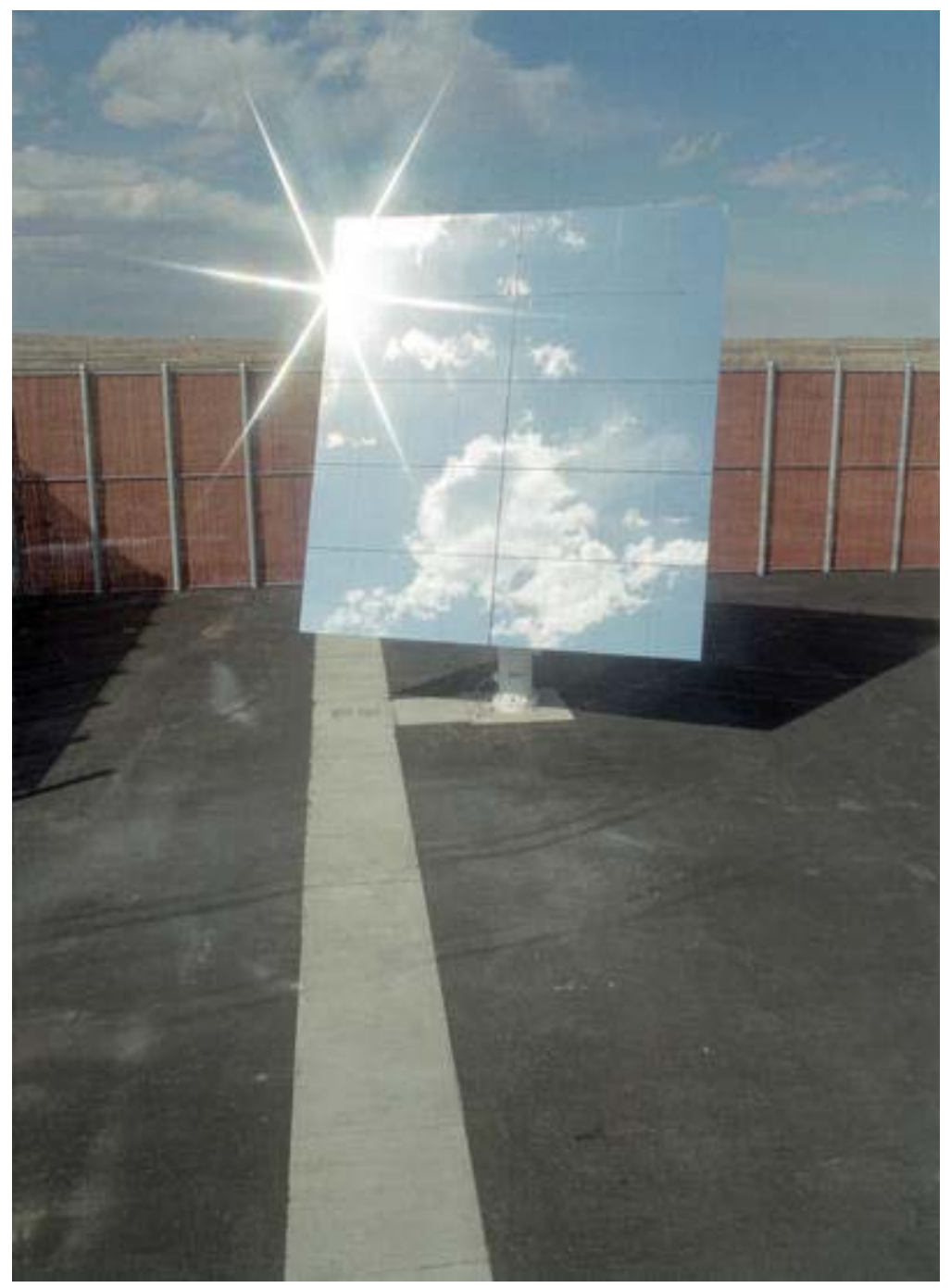




\section{Highly Oriented Laser Ablated Thin Films of $\mathrm{SnO}_{2}$ for Efficient $\mathrm{H}_{2}$ Sensor}

K.I. Gnanasekar, David Jones, and Rambabu Bobba, Surface Science, Spectroscopy and Solid State Ionics Laboratory, Department of Physics

\section{Program Objective}

The desirable factors of the good semiconductor sensor are high sensitivity, high selectivity and short response and retrace times. Of these, sensitivity will be enhanced in structures having maximum specific surface area of the material and hence, the trend to maximize the specific surface area of the particle thereby reducing the average grain size using different chemical routes is seen from the literature [1-2]. Sensors with short response and retracing times can be achieved by maximizing the surface area to volume of the material which is better accomplished in thick or highly porous bodies made of nanocrystallites. Alternatively, engineering of complex oxide surfaces for chemical sensors, that is, the control of geometric and electronic structures of surfaces at the atomic scale can be achieved in thin films [3]. Hence, the development of deposition techniques for processing the films consisting of interconnected crystallites together with high surface area to volume ratio has been the goal of recent studies. A systematic investigation on growth, microstructural and sensor characteristics of highly oriented and randomly oriented thin films of $\mathrm{SnO}_{2}$ have been carried out. Thin pulsed laser $(\mathrm{KrF} ; \mathrm{l}=248 \mathrm{~nm})$ ablation technique and the deposition parameters were optimized to realize the in-situ growth of high quality sensor-grade films. Sensors made of a-axis orientated films [films deposited on (100) $\mathrm{LaAlO}_{3}$ at $525^{\circ} \mathrm{C}$ ] exhibited an exceptionally high sensitivity of 30 to $40 \%$ even for $1 \mathrm{ppm}$ of $\mathrm{H}_{2}$ at $310^{\circ} \mathrm{C}$ with a shorter response time of about $15 \mathrm{sec}$. However, the retrace time was very long (about $20 \mathrm{~min}$ ). Sensors made of predominantly (101) orientated films [films grown at $525^{\circ} \mathrm{C}$ on (1102) sapphire] exhibited an exceptional sensitivity of $90 \%$ even for $5 \mathrm{ppm} \mathrm{H}_{2}$ at $300^{\circ} \mathrm{C}$ also had remarkably short response times of a-axis oriented films as well as the quick retracing times of polycrystalline films. Microstructure of these films as studied through atomic force microscopic technique (AFM) reveals that the films are highly granular with average size of about $150-200 \mathrm{~nm}$ which is ten times larger than critical size which is about $8 \mathrm{~nm}$, a criterion required for obtaining high sensitivity. (The Debye length, LD of $\mathrm{SnO}_{2} @ 4 \mathrm{~nm}$ and the critical grain size is therefore $2{ }^{\prime} \mathrm{LD}$, which is $8 \mathrm{~nm}[4]$ ).

\section{References}

[1] P.T. Moseley and B.C. Tofield (eds.) Solid State Gas Sensors, Adam Hilger, Bristol and Philadelphia (1987).

[2] N. Barsan, M. Schweizer-Berberich and W. Gopel, J. Anal. Chem. 365, 287 (1999).

[3] D.J. Leary, J.O. Barnes and A.G. Jordan, J. Electrochem. Soc. 129, 1383 (1981).

[4] J. Cheung and J. Horwitz, MRS Bull. 17, 231 (1992). 


\section{Nanocrystalline $\mathrm{LiCo}_{1-\mathrm{X}} \mathrm{NiXO}_{2}(0 £ X £ 0.3)$ for Li-lon Batteries}

K. I. Gnanasekar, Jabari Robinson, and Rambabu Bobba, Surface Science and Solid State Ionics Laboratory, Department of Physics

\section{Program Objective}

Nanocrystalline $\mathrm{LiCo}_{1-\mathrm{x}} \mathrm{Ni}_{\mathrm{x}} \mathrm{O}_{2}(0 £ \mathrm{x} £ 0.3)$ - a promising cathode material for rechargeable lithium batteries has been successfully prepared by a novel soft chemical route. Both the formation of the metal-glycine complex and subsequent decomposition of the same at low temperatures under carefully controlled oxygen flow play a critical role in the formation of nanocrystalline material. The thermal history of the as-prepared gel is established by differential thermal analysis (DTA) and thermogravimetric analysis (TG). Powder x-ray diffraction (XRD) and transmission electron microscopy (TEM) confirm the formation of layered a- $\mathrm{NaFeO}_{2}$ structure at temperature as low as $330^{\circ} \mathrm{C}$. The exothermic combustion reaction of the organic precursors, which generates high temperature, should be avoided as it results in the spontaneous growth of large crystals. High-resolution transmission electron microscopy (HRTEM) investigation reveals that the particle size of $\mathrm{LiCo}_{0.7} \mathrm{NiO}_{3} \mathrm{O}_{2}$ heated at $400^{\circ} \mathrm{C}$ is in the range of $10-15 \mathrm{~nm}$. Substitution of nickel retards the crystal growth. Solid state 6Li-MAS NMR investigation reveals that the micro-structural short range ordering of nickel ions in $\mathrm{LiCo}_{1-\mathrm{x}} \mathrm{NixO}_{2}(0 £ \mathrm{x} £ 0.3)$ is minimum at lower processing temperatures. 6Li-MAS NMR studies show that considerable amount of short range ordering of nickel ions is observed when the calcination temperature is raised beyond $800^{\circ} \mathrm{C}$ indicating that the upper limit for processing temperature is around $750^{\circ} \mathrm{C}$. These materials were fabricated into thin electrodes using polyvinylidene fluoride as polymer binder and the electrochemical properties such as charge/discharge and impedance were evaluated. The electrodes cycled well with a coulombic efficiency of close to one. 


\section{Nanocrystalline $\mathrm{La}_{1-x} \mathrm{Sr}_{x} \mathrm{MnO}_{3}(0 £ \times £ 0.3)$ for Solid Oxide Fuel Cells}

K. I. Gnanasekar, Kandace Thomas* and Rambabu Bobba, Science and Solid State Ionics Laboratory, Department of Physics, Southern University and A\&M College

\section{Program Objective}

$\mathrm{La}_{1-\mathrm{x}} \mathrm{Sr}_{\mathrm{x}} \mathrm{MnO}_{3}$ is currently used as an electrode material in solid oxide fuel cells (SOFCs) because of its high electronic conductivity, good chemical stability and compatibility with other cell components even at operating temperatures as high as $1000^{\circ} \mathrm{C}$. However, prolonged operation of the cell at these elevated temperatures results in reduced life-time due to unwanted slow chemical reactions among cell components and with the support frame that is normally made of alumina. Therefore, operating the fuel cell at reduced temperatures is expected to improve the efficiency and life-time of the cell. With this in view, efforts are being made to reduce the operating temperature of the fuel cells by using alternate electrode and electrolyte materials with improved structural and transport properties. Alternatively, one approach is to make the existing components of the fuel cell materials in nanostructured form as they provide larger specific surface area which might promote the catalytic reaction on the surface. In this project, we have prepared nanocrystalline $\mathrm{La}_{1-\mathrm{x}} \mathrm{Sr}_{\mathrm{x}} \mathrm{MnO}_{3}$ using a new solution chemistry technique and the processing parameters were optimized. The thermal history of the as prepared gel is investigated by differential thermal (DTA) and thermogravimetric analysis (TGA). Formation of La $\mathrm{L}_{1-}$ ${ }_{\mathrm{x}} \mathrm{Sr}_{\mathrm{x}} \mathrm{MnO}_{3}$ starts at temperatures as low as $575^{\circ} \mathrm{C}$. Powder $\mathrm{x}$-ray diffraction analysis was used to check the crystallographic phase purity of nanocrystalline $\mathrm{La}_{1-\mathrm{x}} \mathrm{Sr}_{\mathrm{x}} \mathrm{MnO}_{3}$. Transmission electron microscopic investigation (TEM) reveals that the grain size of samples prepared at $575^{\circ} \mathrm{C}$ were in the range of 20-30 $\mathrm{nm}$. 


\title{
An Improved Plate Making Technique for Reducing the Growth of $\mathrm{PbSO}_{4}$ Crystals in Lead Acid Batteries
}

\author{
David Jones, Rambabu Bobba, Science and Solid State Ionics Laboratory, Department of \\ Physics, Henry Cathrino, U.S. Army TACOM, Warren, MI 47397-5000
}

In NREL-REAP 2000 conference, we have earlier reported an evidence for the formation of PbSO4 crystals during cycling (charge/discharge) process in lead acid batteries used in US. Army TACOM. In general, military vehicles tend to be stored for extended periods of time before being used for service. All batteries self-discharge, (lose their charge) when they sit. Because this is a chemical action, higher temperatures cause batteries to self-discharge quicker. A battery that only loses $3 \%$ of its charge a month at $770^{\circ} \mathrm{F}$, like a good maintenance-free absorbed electrolyte. Batteries used in TACOM vehicles lose $10 \%$ a month at $950^{\circ} \mathrm{F}$. A flooded cell battery can lose $5 \%$ a week and have a $20 \%$ a week self-discharge rate at $950^{\circ} \mathrm{F}$. When they near the end of their useful life the self-discharge rate can be $50 \%$ a month. When a battery discharges, water is formed and sulphur combines with the lead making lead sulfate. If not recharged soon, the lead sulfate "hardens" and causes a condition called "sulfation". One theory is that the lead sulfate changes from an ionic to a covalent chemical bond and it requires a lot more energy to break this bond apart. This covalent bond doesn't change back to spongy lead or lead peroxide when the battery is recharged, thus lessening the capacity of the battery. Over a short period of time, this sulfate gradually accumulates and crystallizes, clogging the porous plates to the point where the battery will not accept or hold a charge. In addition to sulfation, the water loss causes the sulfuric acid to get stronger, causing damage to both the plates and the grid structure through both corrosion and sulfation. The steam will also carry sulfuric acid into the air, causing corrosion to the wiring leading to the battery, as well as the battery mounting hardware.

To prevent the sulfation process and to minimize the formation of $\mathrm{PbSO}_{4}$ crystals, during this academic year, we have attempted to develop a new manufacturing technique for valve regulated lead acid batteries. This involves the use of hydrogen peroxide to replace sulfuric acid during the paste making process and the application of no-curing process for plate formation. This technique can greatly simplify the manufacturing process, avoid the formation of $\mathrm{PbSO}_{4}$ crystals, reduce production time and cost and provide plate A different electrochemical reaction mechanism may be involved during $\mathrm{H}_{2} \mathrm{O}_{2}$ based plate formation process. Plates made from new pastes can be assembled directly into a battery case after pasting and then a case formation can be performed directly, without undergoing conventional curing process.

\section{Introduction}

Plates of lead acid batteries have been produced over a century ago from lead dust, a mixture of lead monoxide and metallic lead (free lead). This material is generally satisfactory, but the metallic lead content must be completely oxidized before the plate formation. In the conventional lead content must be oxidized before the plate formation. In the conventional lead acid battery manufacturing process, water and sulfuric acid are used to mix the lead dust into paste. After pasting the plates have to be treated through curing/drying process to oxidize the free lead in the plate so that there remains less than 5\%. Failure to oxidize the free lead below 
$5 \%$ may cause difficulties during the formation of positive plates, swelling or wrapping or extensive sludge formation. The curing/drying process has to be done under rigidly controlled temperature and humidity conditions to produce good bond between the active material and the grid. This process is time consuming and also increases product cost. Battery plates after the conventional curing/drying treatment are rather rigid and stiff, which are suitable only for the conventional flat plate battery construction, investigation was performed initially to see of the plate curing process could be avoided, and what detrimental effects on the discharge capacity and cycle life would eventuate non curing process was applied. In this study, hydrogen peroxide was used to replace the sulfuric acid during the paste preparation, which is currently used in lead acid battery manufacturing process. Hydrogen peroxide performs the function of converting free lead in the lead dust to oxidizes when it is mixed with lead dust. Plates prepared with new paste were assembled in battery directly without going through the conventional curing process. This not only reduces the processing time and cost, but also make plates with sufficient flexibility when an expanded grid or thin grid is used. Compared with the conventional cured plates, the non cured plate does not show significant decline in the discharge capacity and cycle life. Furthermore, the non-cured plates can be used to make a new cell construction, such as spirally wound cell configuration, which present some advantages over the conventional flat electrode configuration.

\section{Experimental}

Three different concentrations of hydrogen peroxide solutions $(2,5,10 \% \mathrm{~V} / \mathrm{V})$ were tested Table 1 shows the formulae of the conventional paste and new paste prepared in our laboratory.

\begin{tabular}{|c|c|c|c|c|}
\hline Sample Paste & Free Lead & $\begin{array}{l}\text { Specific } \\
\text { Before }\end{array}$ & $\begin{array}{l}\text { e area } \\
\text { fter }\end{array}$ & Paste Density \\
\hline $\mathrm{H}_{2} \mathrm{SO}_{4}$ & $2.5 \%$ & 1.25 & 4.2 & $4.0 \mathrm{gm} / \mathrm{Cm}^{3}$ \\
\hline \multicolumn{5}{|l|}{$\mathrm{H}_{2} \mathrm{O}_{2}$} \\
\hline $2 \%$ & 5.4 & 1.06 & 3.12 & $4.0 \mathrm{gm} / \mathrm{Cm}^{3}$ \\
\hline $5 \%$ & 4.1 & 1.10 & 3.36 & $4.0 \mathrm{gm} / \mathrm{Cm}^{3}$ \\
\hline $10 \%$ & 3.8 & 1.08 & 3.43 & $3.9 \mathrm{gm} / \mathrm{Cm}^{3}$ \\
\hline
\end{tabular}

A load coated glass fibre mesh (with diameter for single thread of $0.75 \% \mathrm{~mm}$ was cut into a mesh $40 \times 35 \mathrm{~mm} 2$ and used as a grid for the test cell. Before pasting, the mesh was pretreated in sulfuric acid solution of 1,28 relative density at $1.30 \mathrm{~V}$ vs. $\mathrm{Hg} / \mathrm{Hg}_{2} \mathrm{SO}_{4}$ reference electrode for a period of $2 \mathrm{hrs}$ to produce an initial surface oxide layer. The treatment was considered to be favorable for bonding the active material to the lead coated grid. Free lead in the lead dust and in the paste was analyzed with a gravemetric method.

Cured and non-cured plates and lead dust were subjected to X-ray Diffraction (XRD) for phase analysis identification. The morphology of the plates was also examined with a scanning electron microscope (SEM). 


\section{Results}

The free lead content of the conventionally cured $\mathrm{H}_{2} \mathrm{SO}_{4}$ based paste and the new non-cured paste are all below $5 \%$, except the one with $2 \% \mathrm{H}_{2} \mathrm{O}_{2}$. These results show that $5 \%$ hydrogen peroxide solution can convert free lead in the paste to lead oxide down to an acceptable level. The specific surface area of the conventional $\mathrm{H}_{2} \mathrm{SO}_{4}$ based paste is slightly higher than that of $\mathrm{H}_{2} \mathrm{O}_{2}$ based pastes.

Phase changes at the positive plate before and after formation were analyzed by XRD Table 2 shows the composition of the plates before and after formation

\begin{tabular}{|c|c|c|c|c|c|c|c|c|c|}
\hline \multirow[b]{2}{*}{ Sample } & \multicolumn{4}{|c|}{ Before Formation } & \multirow[b]{2}{*}{ other } & \multicolumn{4}{|c|}{ After Formation } \\
\hline & $\mathrm{Pb}$ & 3BS & $\mathrm{aPbO}$ & $\mathrm{bPbO}$ & & $\mathrm{aPbO}_{2}$ & $\mathrm{bPbO}_{2}$ & a $\mathrm{PbO}$ & $\mathrm{PbSO}_{4}$ \\
\hline $\begin{array}{l}\mathrm{H}_{2} \mathrm{SO}_{4} \\
\text { paste }\end{array}$ & 2.5 & 21.1 & 71.0 & 5.0 & 0.4 & 8.3 & 70.3 & 10.7 & 10.7 \\
\hline $\begin{array}{l}\mathrm{H}_{2} \mathrm{O}_{2} \\
\text { paste }\end{array}$ & 4.1 & & 86.9 & 4.0 & 5.0 & 30.1 & 42.9 & 15.0 & 12.0 \\
\hline
\end{tabular}

It can be seen from Table 2, before formation, the conventional $\mathrm{H}_{2} \mathrm{SO}_{4}$ based cured plate contains $20 \%$ tribasic lead sulfate $\left(3 \mathrm{PbO} \cdot \mathrm{PbSO}_{4} \cdot \mathrm{H}_{2} \mathrm{O}=3 \mathrm{BS}\right.$ ) and converts to $\mathrm{PbO}_{2}(70 \%)$ after formation. Whereas the new $\mathrm{H}_{2} \mathrm{O}_{2}$ based plate contain mainly lead oxide (90\%) before formation and converts to both $\mathrm{PbO}_{2}(30 \%)$ and $\mathrm{PbO}_{2}(43 \%)$ after formation. After formation, the total $\mathrm{PbO}_{2}$ content of the two types of plates (cured and non cured) is over $70 \%$, which indicates that a similar level of plate formation has been reached. SEM measurements show the non cured plates is prone to form spherical aglomerate which appear denser than that of cured plate. The different crystal morphology between the two plates can be explained by the different phase transformation mechanisms during the plate formation. The non cured plate, which may be formatted from its original state, mainly from $\mathrm{PbO} \ll \mathrm{Pb}^{2+} \ll \mathrm{PbO}_{2}$, without going through the phase transfer of $\mathrm{PbO} \ll 3 \mathrm{BS} \ll \mathrm{PbO}_{2}$. This could involve a lesser volu! me change during the formation and would be favorable for reducing the volume change during the plate formation and subsequent charge/discharge cycling. The positive active material expansion and then the loss banding to the grid are the main concern for the use of non cured plate.

\section{Conclusion}

1. A non-cured $\mathrm{H}_{2} \mathrm{O}_{2}$ based paste plate making technique for making VRLA batteries seems to be simple manufacturing process, reduce production time and cost.

2. The non-cured $\mathrm{H}_{2} \mathrm{O}_{2}$ based paste plate can be formatted as well as conventional cured plate under the same process and have similar cycle life as the cured plate.

\section{Acknowledgments}

This work was financially supported by US Army TACOM. David Jones acknowledges the US DOE NREL -HBCU-PV Program for providing financial assistance during summer 2001. 


\section{References}

1. David Jones, B. Rambabu and Henri Cathrino, NREL-HBCU-REAP 2000 conference

2. D.P.Boden, J.Power Sources, 73 (1998) 56.

3. H.Bode, Lead Acid Batteries, Electrochemical Society, Inc, John Wiley \& Sons, Inc, 1977. 


\section{Increased Energy Costs at SUBR and Suggested Steps for Conservation}

Lashanda Roberson, Rajinder Kakar and Rambabu Bobba, Surface Science and Solid State Ionics Laboratory, Department of Physics

\section{Program Objective}

In recent years, the faculty and staff at Southern University and A\&M College are constantly pressured to reduce energy consumption because of the increased power crisis and energy costs. The administration says the energy costs for a typical 100,000-square-foot building amount to $\$ 90,000$ annually. Unfortunately, many buildings (projects) currently under construction on the drawing boards fail to adequately address energy issues. Some contain only a few energyefficient elements-others ignore energy entirely. These projects may cost less in the short term, but in the long run, the result is higher energy bills for decades to come. In this project, we have actually analyzed the recent energy costs at SUBR and attempted to educate the masses about energy conservation and the need for implementing renewable energy sources such as solar energy, wind energy and other energy conversion and storage technologies. We have focused on implementing an efficient energy management plan that must be necessary to reduce the costs. In this presentation, we will show our detailed investigation on the energy costs with reference to SUBR. 


\section{Predicting Corn Stover Stalk Chemistry from Leaf Spectra Using Near Infrared (NIR) Spectroscopy and Projection to Latent Structure (PLS) Multivariate Analysis}

Evan L. Thomas, Southern University and A\&M College, Baton Rouge, LA, USA 70813; Bonnie Hames, Ph.D., Steven R. Thomas, Ph.D., National Renewable Energy Laboratory, Golden, CO 80401

\section{Program Objective}

As a fuel additive to displace petroleum use, increase octane and decrease carbon monoxide among other air emissions, ethanol is currently being used as an effective component of transportation fuel production. Its use could increase rapidly due to its ability to directly replace methyl tertiary butyl ether (MTBE), a petroleum-derived additive that causes water pollution. Compared to MTBE, ethanol is lower in toxicity, water soluble, biodegradable, and less environmentally threatening. Biomass ethanol, or bioethanol is prepared from vegetative (nongrain) plant material called biomass. In biomass, fibrous material is the major component, and consists of cellulose, hemicellulose, and lignin. In the production of ethanol from biomass, cellulose and hemicellulose are converted into sugars through thermochemical pretreatment, and those sugars are fermented (with microorganisms) to ethanol. Corn stover, or the stalks, the leaves, and the cobs that remain after grain has been harvested, is widely available in the United States, and is among the feedstocks (wood wastes, paper, straw, sugarcane, and bagasse) that offer alternative energy opportunities. This study is part of a larger project that involves the conversion of corn stover into ethanol.

One of the challenges of using corn stover as a feedstock will be the natural, unavoidable chemical variation that it exhibits. A rapid analysis technique has been selected as the analytical method by combining near infrared (NIR) spectroscopy and projection to latent structure (PLS) multivariate analysis. A biomass rapid analysis technique can be developed that provides a complete compositional analysis without any loss of precision or accuracy relative to the calibration methods. For the methods presented, NIR spectroscopy was selected as the basis for the rapid method. NIR spectra contain the essential composition information and the instruments are inexpensive and rugged. Also, near infrared reflectance techniques allow field measurements by using direct sunlight as the NIR source. Theoretically, the chemistry of a corn plant can be predicted by scanning a portion of a mature leaf from the same plant. Therefore, a robust NIR/PLS calibration equation is needed to convert spectroscopic data into compositional information.

As an initial step in determining plant chemistry from leaf chemistry, two groups of stover samples were separated into leaves and stalks and labeled accordingly. Spectra were collected using a Foss NIR forage analyzer. Stalk chemistry was determined by an NIR/PLS method calibration for corn stover. Glucan, xylan, lignin, and protein make up $85-90 \%$ of stover samples, and therefore are the focus constituents for the calibration equations. Calibration equations were created by projecting the chemistry of the stalks into the spectra of the leaves. Many equations were calculated using varying wavelengths of near infrared absorptions, although no reduced wavelength models produced an equation that was superior to the full- 
spectrum model. The next step in improving the NIR/PLS method was to eliminate problematic samples and to identify calibration equations with the best match between leaf spectra and stalk chemistry. Current experimental data shows promise of an effective NIR/PLS method that will be capable of predicting the chemical composition of corn stover from leaf spectra. In the future, this method will be tested in field trials for chemical composition of stover. Eventually, similar methods will be used to determine ethanol production capacity from field-collected spectra. 


\section{Rapid Analysis Of Corn Stover Stalks And Leaves Supporting Biomass Conversion Into Bioethanol}

Adam M. Zachary, Southern University and A\&M College, Baton Rouge, LA. 70813; Bonnie Hames, Ph.D., Steven R. Thomas, Ph.D., National Renewable Energy Laboratory, Golden, CO. 80401

Since at least 1908, ethanol has been used as fuel in the United States. The interest in ethanol was renewed in the late 1970's because of oil supply disruptions in the Middle East. The National Renewable Energy Laboratory (NREL) is the field manager for the Ethanol from Biomass Program sponsored by the Department of Energy (DOE) Office of Fuels Development. Ethanol is a non-fossil transportation fuel that contributes little, if any net carbon dioxide to the atmosphere during production and its use. Also, it is a fuel that can be used as a blend or as a pure fuel, with excellent efficiency and performance. The objective is to develop technologies for producing ethanol from biomass at a cost that will allow the displacement of 3 to 4 percent of current gasoline volumes. Most of the United States bioethanol production is based in the large grain-growing states of the Midwest, where starch from corn kernels is used to produce nearly 6 billion liters (over 1.5 billion gallons) of ethanol annually.

Ethanol can be produced from cellulosic biomass feedstocks such as bioenergy crops, agricultural wastes, forestry residues, and municipal solid waste. Cellulosic biomass is a complex mixture of carbohydrate polymers from plant cell walls including cellulose and hemicellulose, and lignin plus a smaller amount of other compounds generally known as extractives. Ethanol is produced from the fermentation of sugar by various yeast, bacteria, and fungi. The five major sugars are the five-carbon xylose and arabinose and the six-carbon glucose, galactose, and mannose. To produce ethanol from biomass feedstocks, a pretreatment process is used to reduce the feedstock size, break down the hemicellulose to sugars, and open up the structure of the cellulose component. Enzymes break down the cellulose and hemicellulose portions into sugars that are fermented to ethanol. In the industrial process, the lignin is burned as fuel. This process combines the hydrolysis and fermentation steps in one vessel to produce high yields of ethanol. The purpose of biomass conversion into ethanol is to reduce the emissions of carbon dioxide and to make a renewable alternative fuel to gasoline. The overall objective is to make the ethanol commercially profitable.

The reason corn stover was chosen as the biomass for conversion into bioethanol is because of its abundance in the United States, and it is one of the crops that have been identified as an energy feedstock. The natural biomass heterogeneity is a challenge in using corn stover as a feedstock. The chemistry varies within the plant, even from field to field. There are many variables that make the chemistry of the plant different such as the soil, the drainage, and the water. Plus, the areas in which the corn stover are located, the seed variety and the storage of the stover are other chemistry determining factors. Different harvesting methods also effect the chemical composition of the stover analysis. Since it is not possible to control the factors effecting the chemical composition of the stover, the best option is to monitor the chemistry with analytical methods. 
Because wet chemical methods are very expensive and time consuming, alternative methods must be found. Wet chemical methods are administered using standard laboratory procedures (LAP) to determine the complete chemical composition of the biomass sample. A complete compositional analysis includes total solids, total carbohydrates, O-Acyl group, total lignin, ash, total extractives, protein, and involves about 30 individual steps. Though time consuming and costly, these procedures provide high quality data and the values obtained are used to calibrate rapid biomass analysis methods. Using Near InfraRed (NIR) spectroscopy coupled with Projection to Latent Structures (PLS) will reduce the cost of analysis. For example, a complete analysis using traditional wet chemical methods cost $\$ 800-\$ 1000$ per sample and the results take days. In contrast, rapid analysis can perform the same analysis for about $\$ 10$ per sample and the results are available in real-time.

In the mentioned rapid analysis methods, NIR and Projection to Latent Structures (PLS) multivariate analysis are combined for the rapid chemical characterization of corn stover feedstocks. Rapid biomass analysis is as good as wet chemistry, and it can match wet chemistry in precision and accuracy. Rapid analysis allows us to gather information that could not be obtained before. For example, feedstock mapping can only be accomplished by using thousands of samples, and the Rapid NIR/PLS method make the analysis of thousands of samples possible. This project involved the analysis of approximately 60-corn stover samples. The goal is to produce a field analyzer that can be transported into the cornfield. It will be used to simply scan the top of the leaf and map the chemistry of the entire plant. In this step of the project, the corn stover has been divided into stalk and leaf fractions and milled separately in a Thomas-Wiley Scientific Mill. After the milling process, all samples were scanned using a FossNIR 6500 Forage Analyzer. The chemistry of the stover samples was obtained using a Rapid NIR/PLS method developed at NREL. Using WinISI PLS software, equations were developed that correlated the stover chemistry and the spectroscopic patterns in the NIR spectra of the leaves. The purpose of this method is to have a refined equation for predicting the chemistry of the corn stover stalk by simply scanning the leaves. 


\section{NREL PV HBCU Dual-Internship Program}

Richard Douglas Wynn Jr., Southern University A\&M College

\section{Program Objective}

This summer the NREL PV HBCU Internship Program has provided me with dual-internships at the Georgetown Energy Museum in Georgetown, Colorado and at the National Renewable Energy Laboratories in Golden, Colorado. Three days out of the week I work at the Georgetown Energy Museum. The G.E.M. is a 100 years old public service owned hydroelectric facility. About eight years ago it incorporated an electrical history/renewable energy museum. While at GEM I catalog electrical artifacts, informing visitors that come to museum, and writing donation letters for acquiring educational displays.

The second halve of my dual internship program involves me working at the national Renewable Energy Laboratories (NREL). At NREL I work with Bob Evens, Calvin Feik, and a team of chemists and engineers developing a process for the production of hydrogen by catalytic steam reforming of biomass pyrolysis. The biomass used as the feedstock is peanut shells. With the team of engineers I modify, assemble, and operate the laboratory equipment for the steam reformer and pyrolysis vapors. 


\section{Rapid Analysis Of Corn Stover Stalks And Leaves Supporting Biomass Conversion Into Bioethanol}

Adam M. Zachary, Southern University and A\&M College, Baton Rouge, LA. 70813; Bonnie Hames, Ph.D., Steven R. Thomas, Ph.D., National Renewable Energy Laboratory, Golden, CO. 80401

\section{Program Objective}

Since at least 1908, ethanol has been used as fuel in the United States. The interest in ethanol was renewed in the late 1970's because of oil supply disruptions in the Middle East. The National Renewable Energy Laboratory (NREL) is the field manager for the Ethanol from Biomass Program sponsored by the Department of Energy (DOE) Office of Fuels Development. Ethanol is a non-fossil transportation fuel that contributes little, if any net carbon dioxide to the atmosphere during production and its use. Also, it is a fuel that can be used as a blend or as a pure fuel, with excellent efficiency and performance. The objective is to develop technologies for producing ethanol from biomass at a cost that will allow the displacement of 3 to 4 percent of current gasoline volumes. Most of the United States bioethanol production is based in the large grain-growing states of the Midwest, where starch from corn kernels is used to produce nearly 6 billion liters (over 1.5 billion gallons) of ethanol annually.

Ethanol can be produced from cellulosic biomass feedstocks such as bioenergy crops, agricultural wastes, forestry residues, and municipal solid waste. Cellulosic biomass is a complex mixture of carbohydrate polymers from plant cell walls including cellulose and hemicellulose, and lignin plus a smaller amount of other compounds generally known as extractives. Ethanol is produced from the fermentation of sugar by various yeast, bacteria, and fungi. The five major sugars are the five-carbon xylose and arabinose and the six-carbon glucose, galactose, and mannose. To produce ethanol from biomass feedstocks, a pretreatment process is used to reduce the feedstock size, break down the hemicellulose to sugars, and open up the structure of the cellulose component. Enzymes break down the cellulose and hemicellulose portions into sugars that are fermented to ethanol. In the industrial process, the lignin is burned as fuel. This process combines the hydrolysis and fermentation steps in one vessel to produce high yields of ethanol. The purpose of biomass conversion into ethanol is to reduce the emissions of carbon dioxide and to make a renewable alternative fuel to gasoline. The overall objective is to make the ethanol commercially profitable.

The reason corn stover was chosen as the biomass for conversion into bioethanol is because of its abundance in the United States, and it is one of the crops that have been identified as an energy feedstock. The natural biomass heterogeneity is a challenge in using corn stover as a feedstock. The chemistry varies within the plant, even from field to field. There are many variables that make the chemistry of the plant different such as the soil, the drainage, and the water. Plus, the areas in which the corn stover are located, the seed variety and the storage of the stover are other chemistry determining factors. 
Different harvesting methods also effect the chemical composition of the stover analysis. Since it is not possible to control the factors effecting the chemical composition of the stover, the best option is to monitor the chemistry with analytical methods.

Because wet chemical methods are very expensive and time consuming, alternative methods must be found. Wet chemical methods are administered using standard laboratory procedures (LAP) to determine the complete chemical composition of the biomass sample. A complete compositional analysis includes total solids, total carbohydrates, O-Acyl group, total lignin, ash, total extractives, protein, and involves about 30 individual steps. Though time consuming and costly, these procedures provide high quality data and the values obtained are used to calibrate rapid biomass analysis methods. Using Near InfraRed (NIR) spectroscopy coupled with Projection to Latent Structures (PLS) will reduce the cost of analysis. For example, a complete analysis using traditional wet chemical methods cost $\$ 800-\$ 1000$ per sample and the results take days. In contrast, rapid analysis can perform the same analysis for about $\$ 10$ per sample and the results are available in real-time.

In the mentioned rapid analysis methods, NIR and Projection to Latent Structures (PLS) multivariate analysis are combined for the rapid chemical characterization of corn stover feedstocks. Rapid biomass analysis is as good as wet chemistry, and it can match wet chemistry in precision and accuracy. Rapid analysis allows us to gather information that could not be obtained before. For example, feedstock mapping can only be accomplished by using thousands of samples, and the Rapid NIR/PLS method make the analysis of thousands of samples possible. This project involved the analysis of approximately 60 -corn stover samples. The goal is to produce a field analyzer that can be transported into the cornfield. It will be used to simply scan the top of the leaf and map the chemistry of the entire plant. In this step of the project, the corn stover has been divided into stalk and leaf fractions and milled separately in a Thomas-Wiley Scientific Mill. After the milling process, all samples were scanned using a FossNIR 6500 Forage Analyzer. The chemistry of the stover samples was obtained using a Rapid NIR/PLS method developed at NREL. Using WinISI PLS software, equations were developed that correlated the stover chemistry and the spectroscopic patterns in the NIR spectra of the leaves. The purpose of this method is to have a refined equation for predicting the chemistry of the corn stover stalk by simply scanning the leaves. 

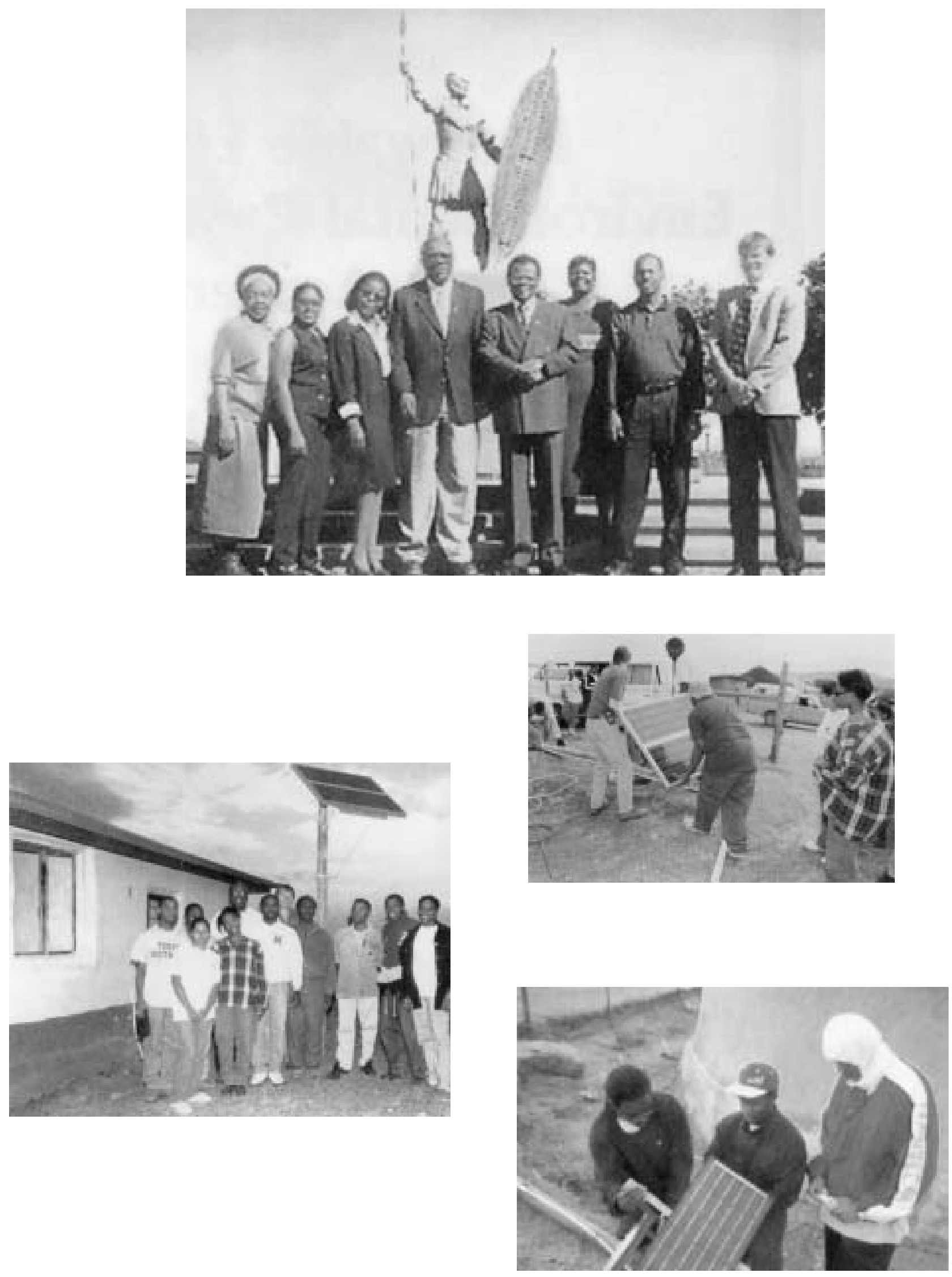


\section{African Solar Village Project}

\section{Rahsaan A. Arscott, Texas Southern University}

Life in the Transkei region of South Africa has remained the same over the years. The Xhosa people of the Transkei have managed to survive in a rural environment which can restrict certain activities to daylight hours. This area has no access to the utility grid which causes not only energy problems but also problems with telecommunications. Texas Southern University's REEP Academy has installed PV systems in the Transkei for the past 4 years to bring lights and even refrigeration to this underdeveloped area of South Africa. With this knowledge of the Transkei and traditional South African life style, the REEP Staff is working on the design of an African Solar Village using solar power that will include both ac and dc. The village will be used to demonstrate the uses of solar electric power and at the same time introduce Americans to pieces of the African culture, South Africa in particular. 


\section{The REEP Experience - From Student to Counselor}

\section{Malcolm Bennett, Texas Southern University}

My participation in the REEP Academy expands over two years. Being a student in the Renewable Energy and Environmental Protection (REEP) Academy exposed renewable energy technology to me that I may have never had the chance to understand. This was my first time ever being introduced to solar energy in any shape or form My years in the Academy have given me much desire to learn and better understand solar technology so much that after graduating from high school, it became my quest to return to the program as a counselor.

As a counselor in the program, it is a pleasure to observe students working in the classrooms and participating in the workshops. Shearing my experiences with students and helping them with their solar projects has made me realize that the REEP Academy really enforces a clear understanding of renewable energy technology. I am happy that the REEP Academy has allowed me to gain an education and experience as a student then returned to assist other students in the Academy to become educated in renewable energy and environmental protection. This paper will highlight my experience in the REEP Academy as a student to counselor. 


\section{Texas Southern University Solar Refrigeration and Solar Lab Projects}

\section{Chien-Kai Chang, College of Science and Technology Texas Southern University}

Work in the solar lab at the College of Science and Technology is helping me understand a lot of the technology that is involved in using solar energy. One such system is the full size batteryfree refrigerator, which incorporates an $\mathrm{AC} / \mathrm{DC}$ power function and a thermal storage system, which maintains cold temperatures when the sun is not shining. The design has enough thermal storage to keep the inside of the refrigerator below 38F. For cloudier regions or higher daily loads a larger compressor and panel are required. In this configuration, a fixed 120 to 170 watt panel is needed. Test sites for the battery free solar refrigerator include the campus of Texas Southern University, New Mexico, and South Africa.

Another research project is understanding how the passive solar track increase electrical output of the photovoltaic modules by $25 \%$ or more compared to modules on fixed mounts. The passive solar trackers are highly cost-effective component for domestic used and it is being demonstrated for solar battery charge system station in the solar lab.

Finally, the REEP students project was developed to ensure that the high school students gain the most practical experiences. This included hands-on activities such as solar racecar and a solar water pump system. 


\section{My REEP Experience}

\section{Deirdre Kinard, Texas Southern University}

During the course of three informative weeks of the REEP academy, my participation was meet with lots of experiences involving the REEP students, classroom sessions, workshop activities and field trip experiences. As a counselor in the REEP Academy, the job of guiding high school students through their daily activities proved to be just as educational for me. Being exposed to the different types of renewable technology made me understand most of the principals of solar energy. Understanding how to build solar cookers, solar cars, solar battery chargers and how to conserve energy were never of much interest to me until now. This is my first year participating in such a program and the experience has changed my life.

Further experience in South Africa with the program has really reinforced my favorite of motto, "Each one, Teach one"; because, my participation in the solar workshop made me understand how important it is for those with knowledge to share. The visit to South Africa also presented a very high level of cultural experience, which was highlighted with a trip to Robben Island and traveling to the rural village to install a solar lighting system in a community pre school. The REEP program stenches far beyond Texas Southern University and my experience is the same. 


\section{Renewable Energy Program In Review}

\section{Oral LaFleur, College of Science and Technology, Texas Southern University}

Texas Southern University College of Science and Technology's involvement in renewable energy has been on the upsurge since 1994. The growth of the program has been tremendous and now includes many projects involving renewable energy, energy efficiency and the REEP Academy. Staff, faculty and students have made optimal contributions to these research efforts and are committed to demonstrating and informing others about renewable energy technologies.

Together, high school and college interns in the REEP academy are given the opportunity to practice what they learn in their prospective programs during the three weeks of the REEP Academy. Traveling around the United States during the last week of the program, some students are exposed to many different types of renewable energy technology at the wind farms in Austin and West Texas, in Colorado at the National Renewable Energy Laboratory and to Washington, DC to the capital to meet with energy policy makers. There is also the solar installation that takes place in South Africa where REEP students and college students learn first hand about the practical use of renewable energy technology.

Renewable energy is a fast emerging technology and students and staff working in the photovoltaic Lab are dedicated structuring programs to meet the growing demands of the REEP Academy. Ultimately, the development of the REEP Academy in the College of Science and Technology has been one of the greatest contributions to the growth and use of the photovoltaic Research and Demonstration Laboratory.

This paper demonstrates the progress and contributions made to educating high school and college students as well as the community by the Renewable Energy and Environmental Protection (REEP) Academy and the Photovoltaic Research and Demonstration Laboratory program at Texas Southern University. 


\section{TSU Battery Free Solar Refrigerator Project Data Collection}

\section{Tony Prince, Texas Southern University}

Over the past two years data was collected from the Battery-Free Solar Refrigerator project at the College of Science and Technology at Texas Southern University Solar lab. This data will be analyzed to determine the performance of the Battery-Free Solar refrigerator. Currently the information gathered is being use as a training tool for students working in the solar. Further analysis will be made of data gathered from South Africa and New Mexico for comparing the performance of the Battery-Free Solar refrigerator at different sites under different conditions. Students and staff and faculty are hopeful that the data will be incorporated in the commercial market for the production of energy effective Battery-Free Solar refrigerators.

This paper will show ways in which the data is being used and how the data will benefit Texas Southern University. 


\section{My Introduction to Renewable Energy}

\section{Sascha S. Sabaroche, Texas Southern University}

Two years exposure to the Renewable Energy Technology was an experience due to the Renewable Energy and Environmental Protection (REEP) Academy Program. As a counselor, the aim was solely geared at being a mentor to the students who were involved in the REEP Academy Program. At the end of the day the introduction to Renewable Energy through REEP Academy allowed me to partake in the program and become more knowledgeable. Also, visitation to the National Renewable Energy Laboratory (NREL) for the two years gave further incentive as to the nature of renewable energy.

The visit to NREL consisted of more hands. For example, the building of a miniature solar car and also, solar cars built by Honda and Toyota which will soon be apart of the future. Solar ovens were created using simple items such as foil, card board box, glue and plastic or glass, which were just as efficient as electric or gas ovens but cheaper in every aspect. Also, the students put these solar ovens made to the test where it was used to bake brownies, cookies and vegetables. Another impressive fixture created was the installation of solar panels on a site near the visitors center and the Wind turbine testing area which done solely to store energy stored in a battery which was used at any given time of the day. Apart from installing solar panels there were panels which needed repairing. Lastly, a tour was given of the wind turbines being tested from other countries. Overall, Renewable Energy was proven to lower cost consumption and beneficial for environmental issues, which this presentation will show. 


\title{
NREL PV HBCU Dual-Internship Program
}

\author{
Emil L. Sims, Texas Southern University
}

\section{Program Objective}

It has been an honor to be selected to participate in the Department of Energy Historically Black Colleges \& Universities Photovoltaic Associates Summer Internship Program (DOE HBCU PV). My internship is looked upon as somewhat unique due to the nature of the assigned tasks. Not only was I privileged to work with NREL's Cadmium Telluride Group, I also conducted tours at the Georgetown Energy Museum (GEM) in Georgetown, Colorado. My first appointment with the Georgetown Energy Museum was to educate tourist on how we use water to produce electricity. During the second part of my venture, I spent a substantial amount of time researching raw material availability, cost, and production rates of the Cadmium Telluride (CdTe) devices develop by our group. Due to the lack of cost modeling tools and pertinent cost data, it was hard to determine the relative value of developing shorter process times. The mission I accomplished was the development of the initial infrastructure using an Excel-spreadsheet to evaluate cost issues associated with CdTe-like manufacturing processes using constraints derived from processes being developed by the NREL CdTe team. The spreadsheet evaluation tool made it easier to gauge the relative impact of processing conditions like time, temperature, and materials utilization. All and all, I was granted a warm, nurturing work atmosphere as well as a rewarding and educational experience. 


\title{
Central State University's Solar Hot Water Heater Project \& Texas Southern University Internship Program
}

\author{
Anthony Williams, Texas Southern University
}

The Central State University solar hot water heater project was implemented for Central State NREL Research Associates to gain direct experience on building and maintaining a solar collector unit. Many weeks were spent on this project and a lot was accomplished. A report was generated that shows the project activities. The education gained while participating in this project helped me to prepare for the internship program at Texas Southern University.

The renewable energy project internship at Texas Southern University was directed to give me hands on experience dealing with high school students involved in renewable energy technology. The position allowed me to assist with the project goal of teaching the how to work with renewable energy technology in the Photovoltaic Research and Demonstration Laboratory in the College of Science and Technology. Some of the projects included solar water pumping, solar car race caring an others. There was also international field trip which included solar installation in South Africa and classroom sessions that included college type exercises to help the high school students better understand what college life is all about in a classroom.

The purpose of this paper is to show the activities of the project at Central State University and my participation in the REEP internship program at Texas Southern University. 


\section{Fannie Posey Eddy}

Biotechnology Center for Fuels

and Chemicals

National Renewable Energy

Laboratory

1617 Cole Boulevard, MS 3511

Golden, Colorado 80401

303-384-6427

fannie eddy@nrel.gov

\section{Bob McConnell}

Center for Basic Sciences

National Renewable Energy

Laboratory

1617 Cole Boulevard, MS 3221

Golden, Colorado 80401

303-384-6419

bob mcconnell@nrel.gov

\section{Syl Morgan-Smith}

Communications and Public

Affairs

National Renewable Energy

Laboratory

1617 Cole Boulevard, MS 1733

Golden, Colorado 80401

303-275-3001

syl morgan-smith@nrel.gov
Joyce H. Lattimore

Assistant Director

Enrollment Management

College of Science and

Technology

Texas Southern University

Houston, Texas

Lattimore JH@tsu.edu

\section{Oral LaFleur}

Program Manager and Research

Associate

College of Science and

Technology

Texas Southern University

Houston, Texas 


\section{Life Emergencies • 911}

Holiday Inn Select Hotel

SW Freeway at Greenway Plaza

Houston, Texas

713-523-8448

TSU Campus Police

713-313-7000

Houston Police

713-222-3131

TSU Health Center

713-313-7174

St. Joseph's Hospital 713-757-1000

Park Plaza Hospital 713-527-5000
Riverside Hospital

713-526-2441

NASA - Johnson Space

Center Mike Ewert 281-434-0240

TSU College of Science and Technology

713-313-7600 or 313-1860

TSU Fax Number

713-313-1853

TSU's Oral LaFleur 713-313-7012

TSU's Joyce Lattimore

713-313-1852 


\section{REPORT DOCUMENTATION PAGE}

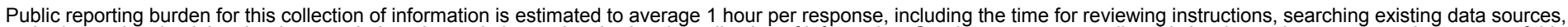

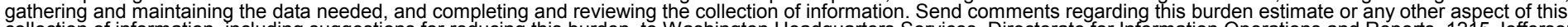

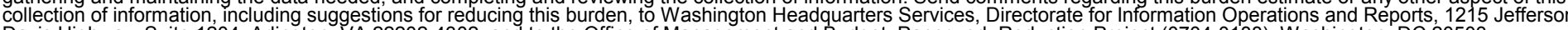
Davis Highway, Suite 1204, Arlington, VA 22202-4302, and to the Office of Management and Budget, Paperwork Reduction Project (0704-0188), Washington, DC 20503.
1. AGENCY USE ONLY (Leave blank)
2. REPORT DATE
August 2002

\section{REPORT TYPE AND DATES COVERED \\ Technical Report, 1995-2002}

4. TITLE AND SUBTITLE

Assessment of the DOE/NREL Historically Black College and University Photovoltaic

Research Associates Program

5. FUNDING NUMBERS

PVP2.2601

6. $\mathrm{AUTHOR}(\mathrm{S})$

Fannie Posey Eddy and Robert D. McConnell

7. PERFORMING ORGANIZATION NAME(S) AND ADDRESS(ES)

National Renewable Energy Laboratory

8. PERFORMING ORGANIZATION REPORT NUMBER

1617 Cole Blvd.

Golden, CO 80401-3393

9. SPONSORING/MONITORING AGENCY NAME(S) AND ADDRESS(ES)

National Renewable Energy Laboratory

1617 Cole Blvd.

Golden, CO 80401-3393

NREL/TP-820-32169

11. SUPPLEMENTARY NOTES

12a. DISTRIBUTION/AVAILABILITY STATEMENT

National Technical Information Service

12b. DISTRIBUTION CODE

U.S. Department of Commerce

5285 Port Royal Road

Springfield, VA 22161

13. ABSTRACT (Maximum 200 words)

This report details the DOE/NREL Historically Black College and University (HBCU) Photovoltaic Research Associates Program, a small but remarkable program that directly affected dozens of minority undergraduate students in ways that changed many of their lives. The progress and accomplishments of undergraduates within the nine participating universities were monitored and assessed through their presentations at an annual NREL-sponsored HBCU conference. Although the funding was small, typically $\$ 400,000$ per year, the money made a significant impact. The best students sometimes went on to the nation's top graduate schools (e.g., MIT) or important management positions in large companies. Other students had opportunities to learn how renewable energy could positively affect their lives and their neighbors' lives. A few were lucky enough to install photovoltaic lighting and water-pumping systems in Africa, and to see and feel firsthand the technical and emotional benefits of this technology for families and villages. Two of the schools, Texas Southern University and Central State University, were particularly successful in leveraging their DOE/NREL funding to obtain additional funding for expanded programs.

14. SUBJECT TERMS colleges; universities; undergraduates; students; research; minority; photovoltaics; PV

15. NUMBER OF PAGES

16. PRICE CODE

17. SECURITY CLASSIFICATION OF REPORT Unclassified
18. SECURITY CLASSIFICATION OF THIS PAGE Unclassified
19. SECURITY CLASSIFICATION OF ABSTRACT Unclassified
20. LIMITATION OF ABSTRACT

UL 